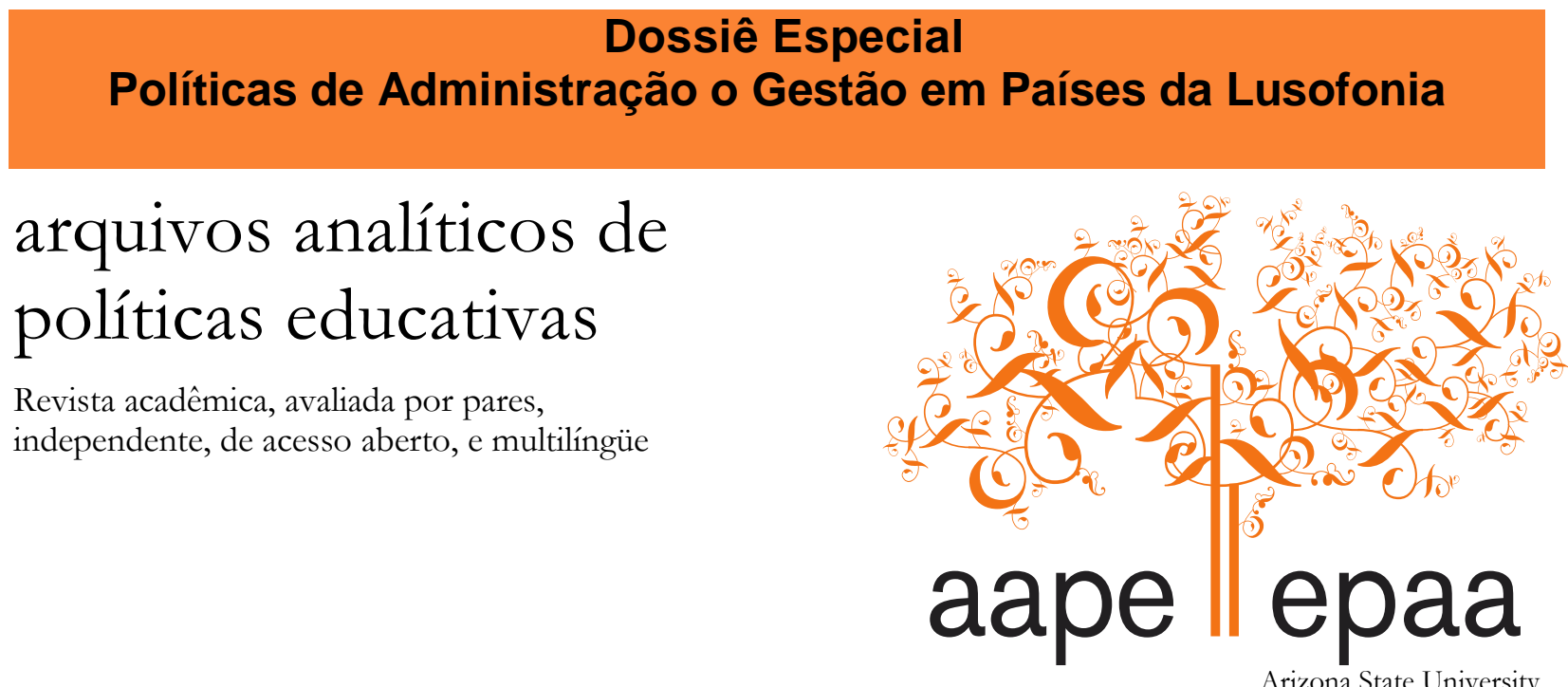

Arizona State University

\title{
A “Escola Cooperativa de Maringá” ou uma Escola com "Ensino Público e Gratuito com Microgestão Privada" (1991-1992): Uma Experiência de Charter School no Brasil Avant la Lettre
}

\author{
Mário Luiz Neves de Azevedo \\ Universidade Estadual de Maringá \\ Brasil
}

Citação: Azevedo, M. L. N. (2018). A "Escola Cooperativa de Maringá” ou uma escola com "ensino público e gratuito com microgestão privada" (1991-1992): Uma experiência de charter school no Brasil avant la lettre. Arquivos Analiticos de Políticas Educativas, 26(132).

http://dx.doi.org/10.14507/epaa.26.2712 Este artigo faz parte do dossiê especial, Politicas de administração e gestão em países da Lusofonia: Perspectivas críticas sobre a nova gestão pública e a pós-burocracia em educação, editada por Almerindo Janela Afonso e Geovana Mendonça Lunardi Mendes.

Resumo: $\mathrm{O}$ artigo analisa a experiência de privatização das escolas públicas municipais em Maringá (Paraná) entre os anos 1991 e 1992, denominada "Escola Cooperativa de Maringá", definida pela administração municipal (1989-1992) como sendo uma escola de "ensino público e gratuito com microgestão privada". Para isto, o artigo apresenta o conceito de Novo Gerencialismo Público (NGP) e demonstra similaridades entre o modelo de privatização havida em Maringá com as charter schools nos EUA.

Palavras-chave: Escola Cooperativa de Maringá; Novo Gerencialismo Público; Escola Pública; Privatização; Charter School 
The "Cooperative School of Maringá" or a school with "public and free education with private micromanagement" (1991-1992): A charter school experience in Brazil avant la lettre

Abstract: The article analyzes the experience of privatization of municipal public schools in Maringá (Paraná - Brazil) between 1991 and 1992, called "Cooperative School of Maringá", considered by the municipal administration (1989-1992) as a school of "public and free education with private micromanagement". The article also presents the concept of New Public Management (NPM) and demonstrates similarities between the model of privatization in Maringá and charter schools in the USA.

Keywords: Cooperative School of Maringá; New Public Management; Public school; Privatization; Charter School

La "Escuela Cooperativa de Maringá" o una escuela con "educación pública y gratuita con microgestión privada" (1991-1992): Una experiencia de charter school en Brasil avant la lettre

Resumen: El artículo analiza la experiencia de privatización de las escuelas públicas municipales en Maringá (Paraná - Brasil) entre 1991 y 1992, llamada "Escuela Cooperativa de Maringá”, considerada por la administración municipal (1989-1992) como una escuela de "educación pública y gratuita con microgestión privada". El artículo también presenta el concepto de Nueva Gestión Pública y demuestra similitudes entre el modelo de privatización en Maringá y las charter schools (escuelas autónomas) en los Estados Unidos de América.

Palabras-clave: Escuela Cooperativa de Maringá; Nueva administración pública; Escuela pública; Privatización; Charter School

\section{Introdução}

O presente artigo trata sobre os conceitos de Novo Gerencialismo Público (NGP) e charter school e procura demonstrar a similaridade do modelo de gestão privada de escolas originado nos EUA, que vem sendo disseminado globalmente, com a experiência gerencial de escolas da rede de ensino da Prefeitura do Município de Maringá (Paraná), entre os anos 1991 e 1992, denominada "Escola Cooperativa de Maringá," definida pelos próprios instituidores públicos como sendo uma escola de "ensino público e gratuito com microgestão privada."

Para isto, o texto dialoga com a produção acadêmica de referência na área de educação sobre charter school, parcerias público-privadas (PPP) e o Novo Gerencialismo Público-NGP, ou NPM, sigla em inglês para New Public Management ${ }^{1}$. O presente artigo ainda recupera dados de pesquisa, tratados no desenvolvimento de dissertação de mestrado, defendida em 1995, pelo autor, e também, sem a pretensão de fazer um état de lieu, atualiza a leitura do que teria sido a primeira experiência de charter school no Brasil, há quase três décadas no Noroeste do Estado do Paraná - em Maringá, um exemplo de privatização próximo do que veio a ser definido como charter school, que, mesmo que a legislação nos EUA a classifique como uma escola pública (Tell, 2015), trata-se (charter school) de uma escola privada, com ou sem a finalidade de lucro, financiada por entes públicos, porém gerenciada com bastante independência em relação às autoridades públicas que lhes

\footnotetext{
${ }^{1}$ De acordo com Robertson e Verger, Christopher Hood (1991) cria “a expressão "nova gestão pública" (NGP) para se referir a um grupo de elementos que incluiu metas de desempenho, a transferência do gerenciamento para os gestores, a especificação de padrões e indicadores, a alocação regida por resultados, auditoria e terceirização de uma série de atividades que haviam sido uma parte central do setor público" (2012, p. 1.136).
} 
repassam fundos. Tell lembra que charter significa "contrato" e "a palavra 'contrato' é uma categoria de mercado e que a contratação e a terceirização são, particularmente sob o neoliberalismo, formas de privatização."2 (Tell, 2015, p. 317).

Em sentido correlato, a chamada "escola-cooperativa de Maringá" foi instituída, entre os anos 1991 e 1992, como uma variação de privatização das gestões das administrações das escolas da rede pública urbana do Município de Maringá (PR). Tal iniciativa ocorreu na gestão municipal do prefeito Ricardo Barros (1989-1993) que, após, foi eleito para cinco mandatos como deputado federal, tendo sido líder no parlamento de diferentes Governos Nacionais (Fernando Henrique Cardoso, Luiz Inácio Lula da Silva e Dilma Rousseff) e Ministro da Saúde do Governo de Michel Temer.

As reformas de cunho liberalizantes e pró-mercado receberam muito incentivo nos anos 1990, porém, como se sabe, as idéias reformistas de cunho neoliberal continuam na ordem do dia, pois, conforme Stephen Ball, "capital privado e negócios de educação global estão interessados em empreendimentos rentáveis em educação" (2014, p. 222). Ou ainda, como notam Robertson e Verger,

há uma vasta e crescente gama de empresas globais de educação que vai desde consultorias como o Cambridge Education, Organizações de Gestão de Ensino (por exemplo, as que operam as escolas charters nos EUA ou as Academias, no Unido Reino), corporações educacionais como Laureate, Cisco Systems, Devry, Bridgewater, Edison Schools e grandes conglomerados de empresas que incluem negócios em educação, como o Apollo Global (2012, p. 1148).

Assim, tendo por referências abordagens críticas fundadas no pensamento de Pierre Bourdieu, Stephen Ball, Roger Dale e Susan Robertson, serão tratados no presente texto os conceitos de Novo Gerencialismo Público e de charter school e será apresentada criticamente a assim chamada "escola-cooperativa de Maringá," também conhecida como sendo uma escola de "ensino público e gratuito com microgestão privada."

\section{Novo Gerencialismo Público e Charter School}

A criação da charter school, uma experiência originalmente norte-americana, é produto do sincrético movimento de reformas de Estado de cunho liberalizante que teve lugar nos EUA, a partir dos governos de Ronald Reagan (1981-1989) e George H. W. Bush (1989-1993), e em outros países, a exemplo do Reino Unido, especialmente com os governos formados pela primeira ministra Margaret Thatcher (1979-1990) e pelo primeiro ministro John Major (19901997), e do Chile, na ditadura de Augusto Pinochet (1973-1990). Neste sentido, charter school é uma organização escolar inspirada em movimentos de liberalização econômica nos EUA e que se torna um modelo de política educacional típico do viria a ser chamado de Novo Gerencialismo Público (NGP ou NPM, do inglês New Public Management). Neste sentido, vale buscar em Christopher Hood a definição do Novo Gerencialismo Público que, pioneiramente, em texto de 1991, cunhou a expressão New Public Management e procurou compreender o que seria essa novidade no mundo da administração pública ${ }^{3}$. Hood salienta que

\footnotetext{
2 “'The word 'contract' is a market category and that contracting and outsourcing are, particularly under neoliberalism, forms of privatization.” (Tell, 2015, p. 317)

${ }^{3}$ Segundo Robertson e Verger, Christopher Hood é o criador da expressão Nova Gestão Pública "para se referir a um grupo de elementos que incluiu metas de desempenho, a transferência do gerenciamento para os
} 
o NGP não é um fenômeno exclusivamente britânico. A ascensão do NGP parece estar ligada a outras quatro 'megatendências' administrativas, a saber: (i) tentativas de retardar ou inverter o crescimento do governo em termos de gastos públicos abertos e dotação de pessoal (Dunsire e Hood, 1989); (ii) a mudança para a privatização e quase-privatização e longe das instituições governamentais centrais, com ênfase renovada na 'subsidiariedade' para a prestação de serviços (ver Hood \& Schuppert, 1988; Dunleavy, 1989). (iii) o desenvolvimento da automação, particularmente em tecnologia da informação, na produção e distribuição de serviços públicos; e, (iv) o desenvolvimento de uma agenda mais internacional, voltada cada vez mais para questões gerais de ges tão pública, formulação de políticas, estilos de decisão e cooperação intergovernamental, além da tradição mais antiga de especializações de cada país na administração pública $(1991, \text { p. } 3)^{4}$.

No Brasil, o NGP surge com força com as reformas administrativas públicas que buscavam maior eficiência nos anos 1990, tento o governo de Fernando Collor de Mello (19901992) como pioneiro nas reformas neoliberalizantes, que se efetivou definitivamente nos dois mandatos do Presidente Fernando Henrique Cardoso (1995-2003), tendo permanecido operante mesmo depois da chegada ao poder dos governos de cunho popular de Luiz Inácio Lula da Silva (2003-2011) e Dilma Roussef (2011-2016). Frise-se que estas reformas, em grande medida incentivadas e influenciadas por organizações internacionais, a exemplo do Banco Mundial, são compatíveis com as várias versões do que se convencionou a chamar de neoliberalismo ${ }^{5}$. De acordo com Oliveira,

O Brasil, assim como outros países da América Latina, enfrentou durante a década de 1990 um processo de reestruturação do Estado que, justificado pelas necessidades de ajustes estruturais, em grande medida em razão da crise da dívida externa, alterou a relação entre Estado e sociedade civil. Essa reestruturação teve como paradigma a adoção dos critérios da economia privada na gestão da coisa pública (2015, p. 629).

Segundo o que prescreve o documento Plano Diretor da Reforma do Aparelho do Estado (Brasil, 1995), redigido sob responsabilidade de Bresser-Pereira, que ocupou no governo FHC o

gestores, a especifi cação de padrões e indicadores, a alocação regida por resultados, auditoria e terceirização de uma série de atividades que haviam sido uma parte central do setor público" (2012, p. 1136).

4 “'The rise of 'new public management' (hereafter NPM) over the past 15 years is one of the most striking intemational trends in public administration. Though the research reported in the other papers in this issue refers mainly to UK experience, NPM is emphatically not a uniquely British development. NPM's rise seems to be linked with four other administrative 'megatrends', namely: (i) attempts to slow down or reverse govemment growth in terms of overt public spending and staffing (Dunsire \& Hood, 1989); (ii) the shift toward privatization and quasi-privatization and away from core govemment institutions, with renewed emphasis on 'subsidiarity' in service provision (cf. Hood \& Schuppert 1988; Dunleavy 1989). (iii) the development of automation, particularly in information technology, in the production and distribution of public services; and (iv) the development of a more intemational agenda, increasingly focused on general issues of public management, policy design, decision styles and intergovernmental cooperation, on top of the older tradition of individual country specialisms in public administration" (Hood, 1991, p. 3).

${ }^{5}$ Segundo Dale, "o desenvolvimento da forma política do neoliberalismo, geralmente chamada de Nova Gestão Pública, que tem como uma das suas características-chave o fato de, em conformidade com o neoliberalismo, não funcionar contra o Estado, mas através dele" (2010, p. 1.104). 
comando do Ministério da Administração Federal e Reforma do Estado, inspirado no NGP, o Estado brasileiro teria quatro setores, sendo 1) Núcleo Estratégico ${ }^{6}$; 2) Atividades Exclusivas ${ }^{7}$; 3) Serviços não Exclusivos ${ }^{8}$; e 4) Produção de Bens e Serviços para o Mercado ${ }^{9}$. O MARE designa um Estado com quatro setores, mas que, na realidade, poderiam ser resumidos a três setores, pois o setor que se dedica às atividades exclusivas de Estado contempla o núcleo estratégico do Estado; um segundo setor, para o que interessa no objetivo do presente artigo, seria aquele que executa serviços sociais e científicos, que na concepção do MARE não seriam serviços exclusivos do Estado e poderiam ser executados por empresas privadas e Organizações Sociais (OSs), estas, por serem consideradas organizações públicas não-estatais, receberiam destinação orçamentária pública; por fim, haveria um setor de produção de bens e serviços pelo Estado para o Mercado que, por incapacidade do setor privado, inclusive a insuficiência de capital, seria formado por empresas que permaneceriam estatais (Brasil, 1995).

Como visto, o núcleo estratégico e os serviços exclusivos de Estado, pela proposta do MARE, não contemplam, entre suas atribuições, o provisionamento de bens públicos de interesse social, como educação, ciência e saúde. Esta política, utilizando a metáfora de Bourdieu, preservaria a mão direita do Estado como estratégica e organicamente ligada ao Estado e dispensaria a ação direta da mão esquerda do Estado, terceirizando sua atuação a empresas particulares e organizações sociais.

Bourdieu, em sua peculiar metáfora, quis dizer que o projeto neoliberal de Estado conservaria a destreza e a força de seu membro superior direito, representado por Ministérios e órgãos incumbidos especialmente das finanças, da repressão, da regulação - enfim do monopólio das violência física e simbólica. Em suas próprias palavras, "penso que a mão esquerda do Estado tem o sentimento que a mão direita não sabe mais ou, pior, não quer mais verdadeiramente saber o que a mão esquerda faz" (Bourdieu, 1998, p. 10).

6 "Corresponde ao governo, em sentido lato. É o setor que define as leis e as políticas públicas, e cobra o seu cumprimento. É portanto o setor onde as decisões estratégicas são tomadas. Corresponde aos Poderes Legislativo e Judiciário, ao Ministério Público e, no poder executivo, ao Presidente da República, aos ministros e aos seus auxiliares e assessores diretos, responsáveis pelo planejamento e formulação das políticas públicas." (Brasil, 1995, p. 41)

7 "É o setor em que são prestados serviços que só o Estado pode realizar. São serviços em que se exerce o poder extroverso do Estado - o poder de regulamentar, fiscalizar, fomentar. Como exemplos temos: a cobrança e fiscalização dos impostos, a polícia, a previdência social básica, o serviço de desemprego, a fiscalização do cumprimento de normas sanitárias, o serviço de trânsito, a compra de serviços de saúde pelo Estado, o controle do meio ambiente, o subsídio à educação básica, o serviço de emissão de passaportes, etc." (Brasil, 1995, p. 41)

8 "Corresponde ao setor onde o Estado atua simultaneamente com outras organizações públicas não-estatais e privadas. As instituições desse setor não possuem o poder de Estado. Este, entretanto, está presente porque os serviços envolvem direitos humanos fundamentais, como os da educação e da saúde, ou porque possuem "economias externas" relevantes, na medida que produzem ganhos que não podem ser apropriados por esses serviços através do mercado. As economias produzidas imediatamente se espalham para o resto da sociedade, não podendo ser transformadas em lucros. São exemplos deste setor: as universidades, os hospitais, os centros de pesquisa e os museus." (Brasil, 1995, p. 41)

9 "Corresponde à área de atuação das empresas. É caracterizado pelas atividades econômicas voltadas para o lucro que ainda permanecem no aparelho do Estado como, por exemplo, as do setor de infra-estrutura. Estão no Estado seja porque faltou capital ao setor privado para realizar o investimento, seja porque são atividades naturalmente monopolistas, nas quais o controle via mercado não é possível, tornando-se necessário no caso de privatização, a regulamentação rígida." (Brasil, 1995, p. 41) 
Sem querer abusar da metáfora de Bourdieu, porém, não é inútil dizer que o NGP representa o Estado com atrofia orgânica de seu lado esquerdo (lado social), pois tende a diminuir sua atuação social e, quando o faz, procura terceirizar suas ações ou privatizar a oferta de bens, relegando ao mercado suas provisões.

Sendo a "Escola Cooperativa de Maringá" uma experiência que aconteceu entre os anos 1991 e 1992, poderia parecer um anacronismo refletir sobre a reforma gerencial do Estado, patrocinada pelo Governo FHC, ocorrida em anos posteriores (1994-2002). Ademais, poderia parecer pedantismo, senão um outro anacronismo, dizer que a experiência de "microgestão privada" das escolas públicas municipais de Maringá tivesse antecipado o modelo de charter schools nos EUA. Por isto, prefere-se, despretensiosamente, apresentar o que consta no subtítulo deste artigo, registrando que a chamada "escola cooperativa de Maringá" caracteriza-se como "uma experiência de Charter School no Brasil avant la lettre", ou seja, a "administração liberal" da Prefeitura do Município de Maringá (1989-1993) desenhou uma política que pode ser tipificada como uma reforma gerencialista na rede de ensino público municipal, sendo que este modelo de gestão escolar, com "ensino público e gratuito com microgestão privada", apareceu, por ironia histórica, um ano antes de a primeira charter school receber matrículas nos EUA, que foi autorizada por lei, em 1991, e começou a operar em 1992 em St. Paul, no Estado de Minnesota $^{10}$, e, ainda mais irônico, antes de o ordenamento jurídico do Brasil permitir que uma empresa privada, "cooperativa" ou Organização Social (OS) pudesse receber recursos públicos para administrar, autonomamente, uma escola pública.

A propósito, os defensores da reforma gerencial nas escolas municipais de Maringá não encontraram respaldo jurídico-legal para manter a "microgestão privada" das escolas públicas municipais. Assim, como resultado da judicialização do conflito entre o público e o privado, algo que será analisado neste artigo mais à frente, o Poder Judiciário dá provimento ao requerido pelos defensores da educação pública, retornando o caráter público das escolas municipais em $1994^{11}$.

A Reforma Gerencial do Estado, a partir do Governo de FHC, conforme declara o próprio Ministro do MARE, Bresser-Pererira, foi inspirada na NGP, após leitura, entre outras obras, do livro Reinventando o Governo, de Osborne e Gaebler (Bresser-Pereira, 2001). Para melhor equipar-se teoricamente e para conhecer uma experiência de governança gerencial, Bresser-Pereira viajou para a Inglaterra, logo após ter sido nomeado Ministro, para "tomar conhecimento da bibliografia que recentemente havia se desenvolvido, principalmente naquele país, a respeito do assunto, sob o título geral de Nova Gestão Pública” (Bresser-Pereira, 2001, p. 22).

${ }^{10}$ Diane Ravitch (2017) registra que "the first law authorizing charter schools was authorized by Minnesota in 1991, and the first charter school opened in St. Paul in 1992. The original idea of charters was that they would enroll students with high-needs, would try new approaches, and would share what they learned with the public schools. They were not intended to be competitors with public schools, but to be akin to research and development centers, abetting the work of the public schools. Now, 25 years later, the charter sector has burgeoned into nearly 7,000 schools enrolling some three million students. Some charters are corporate chains. Some are religious in character. Some operate for profit. Some are owned and run by noneducators".

${ }^{11}$ No Brasil, mesmo com a Reforma Gerencial, segundo o princípio da legalidade na administração pública, o servidor público somente pode fazer o que prescreve a lei, diferentemente da esfera privada, cujos aderentes podem fazer tudo o que a lei não proíbe. Em outras palavras, o princípio da legalidade consiste na limitação da atuação do servidor público, o administrador público pode fazer somente o que a lei permite, enquanto os gestores privados podem atuar livremente, desde que não haja proibições por lei. 
Desta forma, mesmo que o Ministro Bresser-Pereira não queira declarar a existência das marcas do neoliberalismo em sua Pasta, porém, a reforma gerencial no Brasil, a partir do Plano Diretor da Reforma do Aparelho do Estado, de 1995, torna-se referência para o enfraquecimento de direitos sociais e para o avanço do individualismo, resignifificando o sentido do conceito de público, consagrado na Constituição da República do Brasil de 1988, e dando a partida a uma onda de privatizações de empresas estatais (comunicações/telefonia, energia, água, esgoto, rodovias, siderúrgicas etc.). Nas palavras do próprio Bresser-Pereira, o MARE buscou elaborar, ainda no primeiro semestre de 1995, o Plano Diretor da Reforma do Aparelho do Estado e a emenda constitucional da reforma administrativa, tomando como base as experiências recentes em países da OCDE, principalmente o Reino Unido, onde se implantava a segunda grande reforma administrativa da história do capitalismo: depois da reforma burocrática do século passado, a reforma gerencial do final deste século. As novas idéias estavam em plena formação; surgia no Reino Unido uma nova disciplina, a new public management, que, embora influenciada por idéias neoliberais, de fato não podia ser confundida com as idéias da direita; muitos países social-democratas estavam na Europa envolvidos no processo de reforma e de implantação de novas práticas administrativas. O Brasil tinha a oportunidade de participar desse grande movimento de reforma, e constituir-se no primeiro país em desenvolvimento a fazê-lo (2001, p. 23).

Não obstante, o Estado Brasileiro, há tempo, sofrer saques e capturas (econômicas e politicas) por frações de classe e grupos sociais, em especial por rentistas ${ }^{12}$, em que determinados atores sociais aplicam mecanismos (legais e ilegais) de apropriação de fundos e de confusão com as rubricas públicas, o que, entre outras marcas, permitiu que pensadores a respeito do Brasil classificassem o Estado brasileiro como "patrimonialista" (Faoro, 2000; Fernandes, 2006; Hollanda, 1995), com características eminentemente pré-burocráticas ${ }^{13}$, a reforma gerencial do Estado brasileiro, baseado em um discurso anti-burocrático e contrário a privilégios, paradoxalmente, abriu espaços para a ascensão de "novos" quadros de Estado no campo burocrático (campo do poder), especialmente aqueles lotados nas agências de regulação e nos Ministérios da Fazenda e do Planejamento e no Banco Central. Além disso, com a reforma gerencial, certas frações da burguesia (não-industrial) brasileira, principalmente ligadas às finanças e à prestação de serviços, associadas ou não a grupos transnacionais, ganhassem maior preponderância no País. No entanto, paradoxalmente, a reforma gerencial no Brasil é proposta logo após o Congresso Nacional ter acabado de aprovar a Constituição da República Federativa do Brasil (CF), em 1988, procurando firmar os princípios da democracia após 21 anos de

12 A característica essencial do fenômeno Rent seeking, de acordo com Bhagwati, é a de se que se trata de um tipo de atividades que "representam maneiras de obter lucros (ou renda) por intermédio de atividades diretamente improdutivas socialmente. Isto é, geram rendimentos pecuniários, mas não produzem bens ou serviços que teriam uma função de utilidade direta ou indireta via aumento da produção" [Tradução nossa] (1982, p. 989).

${ }^{13}$ Apesar de, conforme nota Sell, "alguns autores têm advogado a tese de que as apropriações teóricas dessa ferramenta weberiana e sua aplicação como instrumento de interpretação da realidade sócio-política do Brasil seriam equivocadas ..., 'ideias fora de lugar' (Schwartz, 1982) (. . .).esse conceito estaria sendo utilizado de modo ahistórico (Souza, 2015), seja ainda porque o sentido semântico mobilizado diverge do original (Campante, 2003)" (2016, p. 2). 
ditadura militar (1964-1985), reconhecendo inclusive os princípios clássicos da administração pública, compatíveis com o que se chama de racionalidade burocrática. Assegura o Art. 37 da CF de 1988:

Art. 37. A administração pública direta e indireta de qualquer dos Poderes da União, dos Estados, do Distrito Federal e dos Municípios obedecerá aos princípios de legalidade, impessoalidade, moralidade, publicidade e eficiência e, também, ao seguinte: I - os cargos, empregos e funções públicas são acessíveis aos brasileiros que preencham os requisitos estabelecidos em lei, assim como aos estrangeiros, na forma da lei; II - a investidura em cargo ou emprego público depende de aprovação prévia em concurso público de provas ou de provas e títulos, de acordo com a natureza e a complexidade do cargo ou emprego, na forma prevista em lei, ressalvadas as nomeações para cargo em comissão declarado em lei de livre nomeação e exoneração; (...)V - as funções de confiança, exercidas exclusivamente por servidores ocupantes de cargo efetivo, e os cargos em comissão, a serem preenchidos por servidores de carreira nos casos, condições e percentuais mínimos previstos em lei, destinam-se apenas às atribuições de direção, chefia e assessoramento.

A propósito, após quase três décadas da promulgação da CF do Brasil, quer parecer que a pedra de toque da reforma gerencial no Brasil, no que se refere à questão fiscal-orçamentáriofinanceira, ao menos até a contemporaneidade, seja a aprovação do Novo Regime Fiscal (NRF), que tramitou na câmara Federal como Proposta de Emenda Constitucional 241/2016, depois renumerada no Senado como PEC 055/2016, e aprovado como Emenda Constitucional EC 95, que tem por objetivo o congelamento das despesas primárias (gastos e investimentos, em especial nas áreas sociais), mas não restringe e nem menciona as despesas financeiras (juros e amortizações sobre a dívida púbica), que compromete grande parte do orçamento nacional (Azevedo, 2016). Recorrendo à mencionada metáfora de Bourdieu, Azevedo (2016) afirma que o "poder Executivo, ao propor o NRF e obter sua aprovação no legislativo, busca a legalização da reação da 'mão direita' do Estado contra os avanços (e os futuros atos) da 'mão esquerda', constitucionalizando o constrangimento da oferta de bens públicos" (p. 237). ${ }^{14}$

O NGP, a despeito de combater o "burocratismo", fortalece um dado grupo burocrático, robustecendo setores de Estado incumbidos do controle, da avaliação e da guarda do tesouro fiscal. O NGP é uma resposta conservadora, por intermédio da mão direita do Estado, à Administração Pública Progressista ( em inglês, Progressive Public Administration [PPA]) que era mais sensível às demandas sociais provisionadas diretamente pela mão esquerda do Estado na forma de bens públicos (educação, saúde, habitação, transporte público etc.), especialmente no Brasil, cuja Constituição Federal de 1988, recebeu o cognome de "Constituição Cidadã." Como percebeu Hood,

14 O campo do poder ou o Estado amplo é a unificação dos diferentes campos sociais. De acordo com Bourdieu (1996), "o Estado é resultado de um processo de concentração de diferentes tipos de capital, capital de força física ou de instrumentos e coerção (exército, polícia), capital simbólico, concentração que, enquanto tal, constitui o Estado como detentor de uma espécie de metacapital, com poder sobre os outros tipos de capital e sobre seus detentores (...). Segue-se que a construção do Estado está em pé de igualdade com a construção do campo do poder, entendido como o espaço do jogo no interior do qual os detentores de capital (de diferentes tipos) lutam particularmente pelo poder sobre o Estado, isto é, sobre o capital estatal que assegura o poder sobre os diferentes tipos de capital e sobre sua reprodução (notadamente por meio da instituição escolar) (pp. 99-100). 
os fundamentos do NGP estavam na reversão de duas doutrinas cardeais do PPA; isto é, diminuir ou remover as diferenças entre os setores público e privado e mudar a ênfase do processo de responsabilização (accountability) para um de seus grandes elementos, o de resultados. A contabilidade seria um elemento-chave nessa nova concepção de prestação de contas, pois refletia alta confiança no mercado e nos métodos de negócios privados (...) e baixa confiança nos servidores públicos (...)(1995, pp. 94-95). ${ }^{15}$

Justificando-se como uma teoria de combate ao "burocratismo", o NGP estimula a criação de um núcleo estratégico de controle sobre a máquina pública. As reformas orientadas pelo NGP tendem a diminuir níveis hierárquicos, tratar o cidadão como cliente ou consumidor e a valorizar uma aristocracia de gestores ${ }^{16}$ preocupados, prioritariamente, com planilhas, indicadores, benchmarks e manuais de "boas práticas", procurando tornar o Estado mais enxuto e eficaz, de maneira que suas atividades sejam executadas, mais produtivamente, por menos servidores. Aucoin (1990), ao tratar sobre a influência do "gerencialismo" nas reformas de Estado, resume o discurso pró-reformista:

as burocracias inchadas podem ter gorduras cortadas e tornarem-se econômicas [nãoperdulárias e eficazes] no uso de recursos organizacionais, a produtividade pode ser melhorada, executando as tarefas de maneira mais criativa e, portanto, de forma mais eficiente, e a efetividade pode ser alcançada prestando-se mais atenção à missão da organização, seu pessoal e seus clientes/consumidores (p. 118) ${ }^{17}$.

Lima (2016), ao tratar da hiperburocracia, afirma que o discurso do NGP pode ser interpretado como um aprofundamento da lógica burocrática, ao estilo do que Weber analisou em relação ao Estado, promovendo de modo exacerbado a lógica da eficácia e da eficiência e permitindo que grupos burocráticos (aristocracias?) atuem de maneira mais livre e desenvolta a bem das finalidades por estes mesmos grupos encetadas (não exatamente a bem do serviço público).

Na prática, conforme alerta Ball (2014), as reformas de Estado baseadas no NGP, essencialmente, fortalecem grupos que transitam dentro e fora do Estado e que mantêm lealdade não ao Estado mas ao "dinheiro," ao "capital," e à doutrina "neoliberal." Isto, contraditoriamente, acontece por meio do próprio Estado, pois, de acordo com Bourdieu, "é o Estado que organiza em nossas sociedades os grandes ritos de instituição, como o rito da investidura do nobre na sociedade feudal" (2014, p. 231). Portanto, por intermédio da implementação do NGP, há o fortalecimento de uma aristocracia de Estado (Bourdieu poderia denominá-la como Nouvelle Noblesse d'État), a exemplo de grupos e corporações que produzem indicadores estatísticos, regulam políticas com base em algoritmos e que estão em posição de comando no campo do poder-aqueles que compõem o núcleo estratégico do Estado e que exercem atividades exclusivas de Estado (Bresser-Pereira, 2001).

15 "The basis of NPM lay in reversing the two cardinal doctrines of PPA; that is, lessening or removing differences between the public and the private sector and shifting the emphasis from process accountability towards a greater element of accountability in terms of results. Accounting was to be a key element in this new conception of accountability, since it reflected high trust in the market and private business methods (...) and low trust in public servants (...)" (Hood, 1995, pp. 94-95).

${ }^{16}$ Hood chama esta aristocracia de novos gestores de econocrats e accountocrats (1995, p. 94).

17 "Bloated bureaucracies can be trimmed of fat and become economical in their use of organizational resources, productivity can be improved by doing things more creatively and thus more efficiently, and effectiveness can be achieved by paying closer attention to the organization's mission, its personnel and its customers/clients." 
O Novo Gerencialismo Público combina com a ideia de que estes novos quadros dirigentes de Estado possam ser chamados de uma "Nova Aristocracia de Estado," não que necessariamente sejam novos os burocratas, mas para dizer que determinados atores sociais são alçados e reconhecidos com distinção pelo campo do poder - passando a situar em uma nova disposição no campo burocrático em que o núcleo estratégico e as funções exclusivas de Estado ganham destaque. Estes quadros públicos, para Aucoin (1990, p. 121), são os "superburocratas." Lima (2016) os chamaria de "hiperburocratas". Parafraseando Bourdieu, a "Nova Aristocracia de Estado" ou a hiperburocracia seria a estrutura corporativa-com ossos, músculos e nervos-da mão direita do Estado que, com o NGP, expressam com autorida de (como auctores) "verdades," profecias e diagnósticos sobre todos os negócios e atividades do Estado. Pierre Bourdieu, nas conferências do College de France sobre o Estado, referenciado em Max Weber e refletindo sobre a racionalidade burocrática, chamou os detentores da autoridade de Estado como "profetas éticos" ou "profetas jurídicos", donos de um "discurso destinado a ser unanimemente como a expressão unânime do grupo unânime” (2014, p. 81).

A "Nova Aristocracia de Estado," para além dos quadros efetivos (concursados) para o exercício de funções exclusivas e no núcleo estratégico de Estado, em grande medida é formada por quadros nomeados pelas representações eleitas (os partidos no poder) e ocupam os postos chave de Estado, exercendo em nome do Estado o poder de nomeação de pessoal e de classificação social, pois, como assinala Bourdieu, "uma das funções mais gerais do Estado é a produção e a canonização das classificações sociais" (2014, p. 38) e, ainda, "se há um ato estatal, é justamente a nomeação" (2014, p. 56). Para Aucoin, uma das razões de promoção do NGP pelos políticos, especialmente a "Nova Direita," é o de empoderar os dirigentes em detrimento dos quadros de carreira—da burocracia clássica de Estado no sentido Weberiano. Para isto, também há a expansão dos cargos de livre nomeação para controlar a burocracia formada pelos funcionários efetivos. Nas palavras de Aucoin, com o NGP, “está aberta a expansão da contratação de pessoal de fora do Estado (outsiders), trazido explicitamente para auxiliar no controle das burocracias (...), muitas vezes de maneira dissimulada (...), Todavia, isto decorre de uma desconfiança da burocracia permanente" (1990, p. 121)

Ademais, um dos princípios do NGP é o foco no utente do serviço público, que é tratado pelo reformismo gerencial mais como um consumidor/cliente que se abastece em um mercado de serviços do que como um cidadão que se relaciona com o Estado como sujeito de direitos e deveres, que, em uma democracia, é contribuinte, eleitor, representante, representado e usuário de bens comuns e bens públicos. Por isto, no campo da educação, o discurso de que as reformas devem ensejar escolas que colocam o aluno no centro-como foco principal—não tem um sentido essencialmente humanista, no mesmo sentido, por exemplo, do ideal de Paulo Freire (1996) que, segundo o patrono da educação brasileira, deveria ser o aluno, com referência no conceito de autonomia, capaz de construir conhecimentos e perceber o Mundo a partir de suas conexões, suas sensações e seus sentidos; mas, na escola gerenciada, o aluno que está em foco é um suposto cliente/consumidor de ensino, cuja relação de aprendizagem, baseada em competências, livre-escolha, performatividade e empregabilidade, estimula o individualismo, o empreendedorismo e o mercado.

Lima (2012) nota que a proposta neoliberal de "escolha de oportunidades passou a ser central, fruto de estratégias e racionalidades individuais, típicas de clientes e de consumidores" (p. 33). Em mesmo sentido, Ball (2014), baseado em Peck (2003) diz que o neoliberalismo,

18 "De uma forma geral, as correntes da nova direita querem repensar e propor novos parâmetros para as sociedades capitalistas avançadas frente à crise do Estado de Bem-Estar, seja através da justificativa teórica do antiigualitarismo ou de propostas de cortes nas políticas de bem-estar social” (Alves, 2000, p. 189). 
substrato ideológico das mudanças individualistas, mercadorizantes e de promoção da performatividade, propagandeadas por variadas Organizações Internacionais (OCDE, Banco Mundial, UNESCO etc.), tanto está "lá fora" (no Estado, nas instituições e nas organizações) como está "aqui dentro" (cada cidadão vem sendo reformado pelo neoliberalismo). Em suas palavras,

o neoliberalismo está 'aqui dentro' bem como 'lá fora'. Ao pensar sobre essas práticas, podemos pensar, também, sobre como estamos 'reformados' pelo neoliberalismo, transformados em diferentes tipos de trabalhadores da educação, e como as mudanças endógenas em organizações do setor público tornam possível, ou seja, estabelecem as bases para a substituição exógena - a privatização -, em outras diferentes formas, de serviços de educação pública. $\mathrm{Na}$ sua forma mais visceral e íntima, o neoliberalismo envolve a transformação das relações sociais em calculabilidade e intercâmbios, isto é, na forma de mercado, e, portanto, a mercantilização da prática educacional - por exemplo, nas economias de valor aluno, por meio da remuneração por desempenho, gestão de desempenho (...). As tecnologias neoliberais trabalham em nós para produzir um corpo docente e discente 'dócil e produtivo', e professores e alunos responsáveis e empreendedores. (Ball, 2014, p. 64)

Desta forma, considerando o Estado em seu conceito ampliado (sociedade política + sociedade civil), como ensina Gramsci, e, à maneira de Bourdieu, que o interpreta como um metacampo social, o Estado é o campo do poder por excelência, por isto, permanentemente, é um espaço de alianças e de disputas. Nosella e Azevedo ressaltam que "o Estado é passível de ser objeto de disputa entre atores pertencentes a campos sociais diversos e, concomitantemente, influenciar o arranjo espacial de qualquer campo social e a vida de seus atores" $(2012$, p. 29$) .{ }^{19}$ Neste sentido, o NGP pode ser considerado também como uma ideologia "transcampos" que amalgama diversos atores sociais, detentores de capitais específicos valorizados em seus respectivos campos, contribuindo para a hegemonia do bloco histórico dominante, que favorece as reformas inspiradas na doutrina neoliberal.

Estes atores sociais, juridicamente internos ou externos à organização estatal, consideram-se partes e parceiros do Estado, dispondo-se a estabelecer Parcerias PúblicoPrivadas (PPPs), inclusive por intermédio de think tanks, ${ }^{20}$ ONGs, OINGs e grupos empresariais. Por dentro do Estado, não é inútil ressaltar, também atuam os nomeados para cargos de comissão e comando, ${ }^{21}$ atores sociais que, em desprezo a seu empregador público,

19 Segundo Bourdieu (2014), os “campos estão, pois, em concorrência uns com os outros, e é nessa concorrência que, de certa forma, se inventa o Estado, se inventa uma espécie de poder 'metacampo"' (pp. 556). Bourdieu também afirma que o Estado pode tomar medidas transcampos porque "se constitui progressivamente como uma espécie de metacampo de um campo em que se produz, se conserva, se reproduz um capital que dá poder sobre as outras espécies de capital" (2014, p. 363).

${ }^{20}$ De acordo com Dixon, think tanks são "estas organizações que se apresentam de modo gracioso como fóruns de reflexão, mas que devem ser consideradas como vetores privilegiados do ativismo político de certos intelectuais, pontos de apoio fundamentais para influir sobre os campos campos econômico e político" (1998, pp. 5-6).

${ }^{21}$ Bourdieu relembra a nomeação do Presidente do Banco da França, em 1981, por François Miterrand: "Quando François Mitterrand chegou ao poder, em 1981, recortei artigos [de imprensa] nos quais se dizia: "Fulano de tal, nomeado presidente do Banco da França, amigo pessoal do presidente", o que era o título 
dedicam maior lealdade a seus recomendantes, padrinhos e formadores intelectuais internos e externo $^{22}$. Em resumo, os quadros comissionados tendem a reservar especial lealdade aos que lhes indicaram para o exercício da "função" no Estado e aos que lhes permitem o bônus do exercício do cargo.

\section{A Escola Cooperativa de Maringá: Um Exemplo de Charter School no Brasil antes da Existência da Expressão (Avant la Lettre)?}

Um dos pilares do pensamento neoliberal é a suposta eficiência imanente da gestão privada. Este aforismo é ainda mais valorizado quando se junta ao pré-juízo de que a administração pública é, como se fosse uma imperfeição de origem, perdulária, inchada, ineficaz e ineficiente. Nesse sentido, a Prefeitura do Município de Maringá, no Estado do Paraná, deu início, em 1991, à execução da proposta de uma escola com "ensino público e gratuito com microgestão privada", denominada, para publicidade, de "Escola-Cooperativa". Tal classificação, entretanto, ao analisá-la criticamente, como se perceberá adiante, não condizia com o conceito de "cooperativa", mas, sim, de organização privada com a finalidade de lucro, correspondente ao paradigma privatizante referenciado nas reformas de matiz neoliberal.

A gestão municipal autodenominada de "Administração Liberal," liderada pelo prefeito Ricardo Barros (01/1989 a 01/1993), mesmo admitindo que a educação no Município de Maringá apresentava bons níveis de qualidade, preferiu abrir mão da gestão pública do ensino público. De acordo com documento oficial, "quando assumiu a Prefeitura de Maringá, em janeiro de 1989, o prefeito Ricardo Barros encontrou uma situação bem mais amena, com bons níveis de produtividade, de qualidade e de resultados no ensino público municipal" (Prefeitura do Município de Maringá, 1991a, p. 2). Em seguida, paradoxalmente, o mesmo texto argumenta contra a administração pública:

primeiro, que a eficiência e a racionalidade administrativa são difíceis não apenas no ensino público, mas no serviço público; segundo, que quando ocorre de ser o serviço público perdulário ou ineficiente, isso acontece em grande parte pela própria natureza da administração pública. (Prefeitura do Município de Maringá, 1991a, p. 3).

Analisando os registros e documentos da época, nota que a experiência "cooperativista" de Maringá (1991/1992) foi uma tentativa de privatizar a administração da escola pública, sem privatizar a propriedade pública. De acordo com os gestores, para o financiamento do ensino municipal, :os recursos devem continuar provindo dos cofres públicos e [os serviços públicos] sendo gratuitos para a população, mas a sua aplicação deveria ser gerenciada pela iniciativa privada, com interesses diretos na eficiência de sua aplicação” (Prefeitura do Município de

mais ostensivo da legitimidade da pessoa nomeada e da nomeação. Eis um exemplo que mostra que não se está numa lógica linear tal como o sugere o conceito weberiano de racionalização" (2014, p. 263).

${ }^{22}$ Celso Lafer e Felix Peña, em 1973, chamam a atenção a respeito da influência estrangeira nas políticas do Brasil e da Argentina, "os atores nacionais orientam suas ações para atores nacionais de outra unidade política do sistema internacional para obterem destes um comportamento favorável a seus objetivos. Em certos casos, assumem o caráter de ator 'interno' para um determinado sistema político e passam a participar, internamente, de uma maneira direta ou indireta, no exercício da autoridade política (...). A vinculação por penetração se articula com base na existência de atores internos de um sistema político nacional, com lealdades duais, uma delas orientada para um centro de decisão externo" (apud Azevedo \& Cantani, 2004, p. 164). 
Maringá, 1991a, p.3). Neste sentido, formalmente, para inaugurar o Novo Gerencialismo Público (NGP) por intermédio da "microgestão privada" nas escolas municipais, a Prefeitura do Município de Maringá deveria abrir licitações para selecionar os novos gestores terceirizados. Para, em seguida, realizar, como resultado de cada licitação, um "contrato de prestação de serviço e permissão de uso especial de bem público" entre a Prefeitura e a empresa vencedora. Nos termos deste contrato com o prestador de serviços educacionais, o Município obrigava-se a ceder toda a infra-estrutura à empresa contratada e a pagar uma soma por aluno matriculado na escola. ${ }^{23}$ A empresa prestadora de serviço ficava com o compromisso de oferecer (contratar) os recursos humanos ${ }^{24}$ e assumir a gestão da escola. Explicava o documento de divulgação da Prefeitura Municipal de Maringá,

os professores constituem sociedades para participar de concorrências, pelas quais lhes é entregue a administração de unidades escolares. A sociedade recebe per capita, de acordo com o número de alunos e com a capacitação técnica da equipe. E ganha liberdade para administrar estes recursos da forma mais eficiente, inclusive fixando níveis de vencimentos que - a experiência já prova-podem ser bem melhores que os pagos diretamente pelo poder público (1991a, p. 3).

A terceirização para a provisão de educação, um bem público, por intermédio da transferência da gestão do ensino público municipal a grupos privados, acompanhada de contrapartida financeira e cessão equipamentos públicos, motivou uma Ação Cívil Pública, proposta pelo Ministério Público do Estado do Paraná, contra a Prefeitura Municipal. Vale a pena conferir como é descrito pela Promotoria Pública a relação contraída entre o público e o privado: nesses contratos o Município se compromete a: ceder prédios públicos para instalação da escola, totalmente mobiliados e equipados, inclusive com material básico de cozinha; fornecer gêneros alimentícios básicos; fornecer acervo bibliográfico e material didático, inclusive VÍDEO CASSETE, RETROPROJETOR E AS FITAS RESPECTIVAS; fornecer materiais escolares (grifos no original). À empresa favorecida é reservada tão somente a obrigação de “fornecer o quadro de pessoal para a escola' (Paraná, 1991, p. 5).

Para atrair empresas candidatas nos processos de licitação para a oferta de ensino, ao mesmo tempo em que estimulava professores a constituírem organizações jurídicas para este fim, chamadas pelos promotores do gerencialismo privado de "cooperativas," o marketing oficial enfatizava a possibilidade do lucro. Segundo as autoridades municipais, "beneficiam-se os professores, sócios da sociedade, porque, ao reduzir os custos via eficiência administrativa, aumentam seus ganhos reais e

${ }^{23} \mathrm{O}$ Edital de Tomada de Preços n.008/92-DM/DA, de 05.02.1992, informa o valor a ser pago por aluno matriculado: "Para classes de Pré a 8 a séries, o valor da bolsa aluno "per capita" será até Cr $\$ 38.216,79$, tendo como base o Custo Aluno do mês de fevereiro/92." As propostas de tomadas de preços das empresas prestadoras geralmente apresentavam o valor máximo informado pelo Edital. Conforme constata-se nas propostas das empresas: CENTRO EDUCACIONAL CULTURAL MANUEL BANDEIRA S/C LTDA., INTEGRADO-ENSINO EDUCACIONAL S/C LTDA., TRIS-Trabalho de Integração Social, PRÉESCOLA ESTRELA DA VIDA S/C LTDA. (Paraná, 1991, pp. 230-238).

${ }^{24}$ A cláusula sétima - Das Obrigações do Município, em sua subcláusula primeira, abre a possibilidade do Município arcar, em certas ocasiões, com despesas de pessoal:

SUBCLÁUSULA PRIMEIRA: "Fica acordado entre as partes que, havendo defasagem de conteúdo, devidamente comprovado e autorizado pela Diretoria de Educação, caberá ao Município arcar com o ônus do professor, bem como com a merenda escolar dos alunos (Paraná, 1991, p. 285). 
empenham-se em envolver toda a comunidade no processo de racionalização de custos" (Prefeitura do Município de Maringá, 1991a, p. 10). Os educadores Moacir Gadotti e José Eustáquio Romão interpretaram auspiciosamente a política municipal de "microgestão privada" das escolas. Em obra publicada pelo Ministério da Educação (MEC), intitulada A Educação e o Município, os autores asseveram que "a inovação conseguiu, mesmo no curto espaço de tempo de implantação, uma melhora do padrão de gestão da escola” (1993, p. 27).

No entanto, esta não era uma sensação consensual. Houve forte contraposição a este modelo de "microgestão privada" do ensino, entre os quais, a do educador Paulo Freire que, em entrevista coletiva em Maringá, sem rodeios, declarou que "a educação não deve ser, nunca, fonte de lucro, como uma mercadoria qualquer. Se isto estiver ocorrendo em Maringá, devemos protestar com todas as armas" (O Diario, 1991). A disposição de luta do educador em favor da escola pública é inequívoca. Paulo Freire afirmou na mesma ocasião que, se fosse preciso, ele entraria na contenda ao lado dos cidadãos defensores da manutenção da educação pública. Em suas palavras,

é inadmissível a transferência de responsabilidade do município com a educação para o setor privado. O executivo tem o dever de criar e assistir as escolas municipais. Isso significa um atentado à liberdade, só verificados em governantes autoritários e sem a premissa de trabalhar pelo bem estar de sua comunidade. Espero que o prefeito de Maringá volte atrás nesta verdadeira bandalheira contra o ensino fundamental. Sou totalmente contra e, se for preciso, lutarei a favor da manutenção do ensino público. (Jornal do Povo, 1991, p. 4).

A posição de Freire em favor da resistência e da continuidade da administração pública das escolas sem intermediários terceirizados coincide com o espírito de combate da comunidade de Maringá. Vários segmentos da sociedade posicionaram-se contra a privatização da gestão das escolas públicas do Município de Maringá. Entre outros movimentos de oposição, criou-se o Fórum Maringaense em Defesa do Patrimônio Público, congregando mais de 150 entidades e instituições vinculadas à educação pública e à organização dos trabalhadores, que promoveu várias manifestações contrárias à chamada "escola-cooperativa" de Maringá25.

A maior demonstração de protesto de rua contra a "microgestão privada" das escolas municipais ocorreu no dia 24 de outubro de 1991. O Jornal do Povo registrou, como manchete, "Quase mil pessoas na manifestação contra a privatização da educação.” Este ato de contestação aconteceu em dois turnos, de manhã e à tarde. Nas duas ocasiões houve passeata e concentração na Praça Raposo Tavares, localizada na região central da cidade. Registrou a imprensa local:

$\mathrm{Na}$ parte da manhã, alunos de todos os colégios estaduais realizaram passeata pelo centro da cidade, passando pelos principais colégios, que culminou em concentração cívica na Praça Raposo Tavares, com vários alunos, professores, sindicalistas e políticos fazendo uso da palavra. A concentração dos alunos foi pacífica. Eles passaram pela prefeitura municipal, onde ficaram em frente gritando palavras contra a privatização durante aproximadamente quinze minutos (Baddini, 1991, p. 4).

${ }^{25} \mathrm{O}$ Fórum em Defesa do Patrimônio Público era formado basicamente por cinco partidos (PT, PC do B, PDT, PCB e PMDB), CUT, CPT, UJS, entidades sindicais (SINTEEMAR, SINDP, SISMMAR, URBANITÁRIOS, SINTICOM, SINDPREV, SINTEL, SINTE), entidades estudantis (DCE, UMES), organizações populares, associações de bairros, associações de classe, APMs, pastorais e clubes de mãe. A lista com os nomes completos das entidades componentes do Fórum encontra-se em cópia do abaixoassinado que está apensa ao processo 631/91 constante nas referências bibliográficas desta dissertação. 
Na tarde, além da passeata e concentração na Praça Raposo Tavares, os representantes do Fórum em Defesa do Patrimônio Público entregaram abaixo assinado ao Prefeito Municipal pedindo a anulação das licitações com as empresas educacionais e revogação das privatizações das escolas municipais. $\mathrm{Na}$ mesma reportagem, assinala o jornalista,

À tarde, porém, a mobilização começou a ganhar mais corpo, já contando a presença maciça de professores, pais e alunos das escolas municipais, inclusive das já privatizadas, representantes de entidades de classe, estudantes da UEM e população em geral. Da praça Raposo Tavares, onde as professoras se encontravam concentradas, em protesto contra a privatização, a passeata dirigiu-se até a prefeitura municipal, pela Avenida Getúlio Vargas, onde coordenadores do fórum protocolaram requerimento endereçado ao Prefeito Ricardo Barros (que não se encontrava na cidade), repudiando a privatização das escolas municipais, com 19 mil assinaturas. No documento (...) é solicitada ao prefeito a revogação da privatização das escolas (...)(Baddini, 1991, p. 4).

O Fórum em Defesa do Patrimônio Público, em documento produzido coletivamente, analisa a experiência de "microgestão privada" das escolas municipais e esclarece que não se trata de uma cooperativa escolar, mas sim de execução de um projeto em que a gestão das escolas passa para empresas constituídas para este fim, desvirtuando a essência educativa da escola e tornando preponderante a finalidade do lucro. Segundo o Fórum em Defesa do Patrimônio Público (1991),

com a 'gestão privada' de recursos e serviços públicos que caracteriza esse projeto, a escola pública recebe um tratamento empresarial. A escola desvia-se de seu caráter educativo [grifos no original], colocando-se a serviço de grupos particulares, perdendo a sua condição de direito de cidadãos e dever do poder público. Infere-se dessa lógica que, direta ou indiretamente, a margem de lucro necessária à gestão empresarial acaba saindo do bolso do contribuinte (p. 7).

As manifestações de rua organizadas pelo Fórum Maringaense em Defesa do Patrimônio Público foram uma importante expressão do descontentamento de professores, alunos, pais e membros de diversas entidades contra a "escola-cooperativa." Além disso, diversos foram os textos publicados desaprovando este tipo de gestão escolar. A seguir elencam-se alguns manifestos de agravo à "escola-cooperativa":

1. MOÇÃO EM DEFESA DA ESCOLA VERDADEIRAMENTE PÚBLICA, assinam as APMs-Associações de Pais e Mestres das Escolas Municipais: Fernão Dias, João Gentilim, Luiz Gabriel Sampaio, Renato Bernardi, Maestro Aniceto Matti, Miriam Leila Palandri, Rui Alvino Alegretti, Machado de Assis, Heleton Borba Cortez, Benedito de Souza, Luiz Ribeiro, Odete Alcântara, Delfim Moreira, Jardim Quebec e Laura Parente Bossolã (O Diario, 1991; Jornal do Povo, 1991, p. $5)$;

2. ESCOLA MARKETING: Quando o autor passa a ser o ator, assina o Diretório do PMDB de Maringá (mimeo, 1991);

3. PRIVATIZAÇÃO DO ENSINO: Lucro de quem?, subscrita pelo Rev. Naamã Mendes, Pastor da $1^{a}$ IPI de Maringá (O Diario, 1991, p. 15); “. MOÇÃO DE REPÚDIO À PRIVATIZAÇÃO DO ENSINO ATRAVÉS DA "ESCOLA COOPERATIVA," manifestada no $43^{\circ}$ CONGRESSO BRASILEIRO DE ENFERMAGEM (mimeo, Curitiba, 16.10.91); 
5. NOTA DE REPÚDIO À “ESCOLA-COOPERATIVA,” assinam Eugênio Popovitz e Lélis Vieira, pelo Diretório do PDT; 6. AOS PARANAENSES - EM DEFESA DO CARÁTER PÚBLICO DA ESCOLA, subscrevem o Fórum Paranaense em Defesa da Escola Pública, Gratuita e Universal e o Fórum Maringaense em Defesa do Patrimônio Público (mimeo, 1991);

7. ABAIXO-ASSINADO DESTINADO À PREFEITURA MUNICIPAL DE MARINGÁ PEDINDO A REVOGAÇÃO DA "ESCOLA COOPERATIVA," com 654 folhas contendo 18.079 assinaturas, promovido pelo Fórum Maringaense em Defesa do Patrimônio Público, encaminhado através de ofício, de 24.10.91, firmado por Vera Lúcia Dias de Freitas, Claudemir Romancini e Marino Elídio Gonçalves, representando as entidades componentes do Fórum (Paraná, 1991, pp. 58-60);

8. MOÇÃO AO PREFEITO MUNICIPAL DE MARINGÁ, solicitando o fortalecimento do ensino público e gratuito, enviada pelo Fórum de Reitores das Universidades Estaduais e Municipais Brasileiras, em 25.10.91 (Paraná, 1991, p. 67).

Com mais detalhes, na prática, como ocorria a execução do projeto de "microgestão privada" das escolas e como funcionava este tipo singular de privatização? As empresas organizadas com o fim de gerenciar as escolas municipais recebiam da Prefeitura Municipal de Maringá, além da permissão de uso do prédio e dos equipamentos públicos, um valor por aluno matriculado e materiais de consumo arrolados previamente em contrato entre os entes público e privado. Vale conferir a interpretação do Jornal Folha de S. Paulo, "no sistema de escolas cooperativadas, a Prefeitura entra com o patrimônio, infra-estrutura e o repasse de verbas para os grupos de professores e funcionários que assumem as escolas e as creches" (Maschio, 1992, cad. 3, p. 3). Segundo os educadores Romão e Gadotti,

o objetivo básico da proposta de Maringá é entregar a administração de cada unidade escolar a cooperativas de trabalhadores desvinculadas do poder público, mas a ele prestando serviço e recebendo por produtividade. Com interesse direto nos resultados, os trabalhadores passam a se preocupar com a produtividade, $\mathrm{O}$ desempenho, a pontualidade, a assiduidade e o atendimento à comunidade (...). Essa proposta pressupõe a contratação de empresa (cooperativa), através de licitação, constituída especificamente para esse fim. Essa empresa obriga-se a cumprir uma série de requisitos, entre eles, garantir o cumprimento de princípios metodológicos ditados pela Prefeitura; garantir a criação de um Conselho de Pais e Mestres para avaliação, controle e deliberação sobre as despesas de manutenção da escola; garantir a merenda escolar para todos os alunos no padrão nutritivo estabelecido pela Prefeitura; garantir o número máximo de 35 alunos por sala de aula e a não extinção de turmas durante o ano letivo. Em contrapartida, a Prefeitura cede o prédio da unidade escolar equipado e mobiliado, inclusive com todos os equipamentos básicos de cozinha, repassa os gêneros alimentícios para merenda, fornece uma biblioteca básica e faz o pagamento por aluno matriculado (1993, p. 26).

Das surpresas na pesquisa sobre as "escolas cooperativas" de Maringá, chama atenção posição de relativa aprovação à "microgestão privada" da educação municipal por dois intelectuais, Moacir Gadotti e José Eustáquio Romão, historicamente identificados com o pensamento de Paulo Freire. Entre seus achados, publicados pelo MEC em livro já mencionado, Romão e Gadotti declaram: 
"constatamos efetivamente que os técnicos e professores acreditavam na proposta e estavam muito motivados para o trabalho nessa nova forma de gestão. A experiência de Maringá era uma grande esperança para pensarmos uma gestão da escola cidadã, autônoma (1993, p. 27). Entretanto, na mesma publicação, ambos, contraditoriamente, apresentam decepção com a liderança municipal que implementou a "escola cooperativa de Maringá" e mesmo com a metodologia de relacionamento entre a Prefeitura, a comunidade e os novos gestores escolares. A citação é longa, porém, a bem do respeito aos mencionados educadores, vale a leitura do parecer de Romão e Gadotti:

A proposta foi imposta de cima para baixo, mas foi bem aceita pela comunidade. Pela proposta inicial deveria haver uma valorização do professor via aumento salarial, mas isso não ocorreu, pois a experiência foi totalmente extinguida com a nova administração municipal do inicio de 1993. A relação da escola com a comunidade foi muito intensa. Durante a campanha eleitoral de 1992, os pais se mobilizaram para que a futura administração continuasse o projeto. Em 1992 a proposta gerou grande polêmica alimentada sobretudo pelas atitudes agressivas do prefeito em relação principalmente aos seus opositores do Fórum Maringaense em Defesa do Patrimônio Público que sustentava que as escolas cooperativas, de maneira como foram implantadas, marginalizaram a sociedade da participação do processo. Além disso, o Fórum alegava que a experiência era inconstitucional, pois repassava verbas públicas para entidades privadas com fins lucrativos. O principal problemas constatado na visita e entrevistas que os autores desse relatório fizeram, refere-se a questão da autonomia financeira e administrativa. Houve muita dificuldade em se estabelecer o valor exato do custo-aluno que era reajustado mensalmente. A base de cálculo era muito imprecisa e a margem de manobra dos recursos recebidos era muito pouca (1993, p. 27).

A experiência maringaense de "microgestão privada", absolutamente, não pode ser classificada como uma inovação no sentido da valorização da coisa pública e da cidadania. Isto porque a "microgestão privada" nas escolas municipais era, à guisa de promover a descentralização administrativa, uma forma de o poder político local, o Município, considerado pelo Constituição da República Federativa do Brasil, CF de 1988, um ente federativo, afastar-se do debate sobre a Educação com a comunidade, transformando um assunto essencialmente político em um assunto econômico e contábil. A "microgestão privada" transformava cada escola em uma "unidade de custos" e a rede municipal em um sistema de "produção contínua", caracterizando-se pela formação (produção) em série de alunos, considerados, por este modelo gerencialista, produtos padronizados, cujos custos poderiam ser calculados em planilhas e cuja qualidade de ensino poderia ser aferida pelos resultados em avaliações também padronizadas. Aliás, as avaliações de alto impacto ainda não haviam sido propostas publicamente pelos promotores da "escola cooperativa de Maringá", mas, como afirmou Gadotti, no 10. Seminário sobre Ensino Público e Gratuito com Micro Gestão Privada, promovido pela Diretoria de Educação da Prefeitura Municipal de Maringá, entre os dias 15 e 16 de Setembro de 1992, a descentralização e a autonomia passam por quatro etapas, sendo a última a constituição de um sistema de avaliação. Em suas palavras, conforme anotações de sua conferência,

Eu acho que tem que haver um caminho direto da escola para com a secretaria e vice-versa, sobretudo nos grandes sistemas, nos pequenos sistemas isto é mais fácil. Em primeiro lugar tem que ter clareza política para onde vai se chegar; em segundo lugar, tem que ter sistema de comunicação direta com as escolas; em 
terceiro lugar, a escola tem que ter autonomia para definir o seu projeto; em quarto lugar, tem que haver um sistema de avaliação (...). O Reino Unido está fazendo exatamente isto. A grande reforma do Reino Unido só tem dois pontos fundamentais: 1) autonomia das escolas (...) para elas elaborarem seus projetos (...). A este ponto está associado o dever do Estado, além de avaliar, é apenas o de fornecer recursos. Então com isso, toda essa camada burocrática intermediária desaparece nos grandes sistemas, nos pequenos sistemas até que não há muita burocracia (Gadotti, 1992, anotações de palestra).

Porém, avançando no raciocínio, ainda que pareça ser inglesa a inspiração da "microgestão privada", em virtude das características da descentralização e da proposta de avaliação, porém, na Inglaterra, ${ }^{26}$ as escolas independentes, mesmo sendo financiados por fundos públicos, são auto-administradas por grupos ou organizações não-governamentais sem finalidade de lucro (a exemplo de grupos de caridade e, também, confessionais). ${ }^{27}$ Em Maringá, as empresas gestoras das escolas municipais extraiam lucro dos repasses per capita feitos pelo ente público, pela Prefeitura. Na realidade, o modelo maringaense de terceirização da gestão escolar está mais próximo do que viria a ser chamado de charter school, $^{28}$ vale frisar, autorizada a funcionar legalmente, em 1991, com início efetivo em St. Paul, no Estado de Minnesota, em 1992.

Criação original norte-americana, as charter school são escolas financiadas com recursos públicos, governadas por entes privados que, em grande parte, tem finalidade de lucro e, ainda, podem receber financiamento privado suplementar (individuais, empresariais ou filantrópicas). Theresa Adrião, baseando-se em Mathis e Jimerson, registra a existência nos EUA de três modalidades de privatização, sendo uma delas o modelo de charter school:

a primeira modalidade (vouchers ou choice), que segundo eles não se verifica de forma pura, refere-se à possibilidade das famílias escolherem a escola em que querem matricular seus filhos e serem subvencionadas pelo Estado para garantir essa "escolha". A segunda modalidade, as chamadas escolas charters, seriam instituições privadas com subsídio público e acesso gratuito. Em alguns casos tais escolas se credenciam junto ao setor público por apresentarem projetos

${ }^{26}$ De acordo com Whitty e Power, "em Inglaterra, ainda antes da década de oitenta, a grande maioria das crianças era educada nas escolas do Estado mantidas pelas Autoridades Educativas Locais (AELs) (Local Education Authority, LEAs), democraticamente eleitas, as quais exerciam controlo político e burocrático sobre as suas escolas, mas também muitas vezes proporcionavamlhes um considerável suporte profissional. Depois da vitória do partido Conservador, nas eleições de 1979, os governos de Thatcher e Major iniciaram o desmantelamento do monopólio das AELs das escolas estatais promovendo Decretos Lei Educativos durante a década de 80 e início de 90 . Embora a introdução do Currículo Nacional e o seu associado sistema de avaliação, juntos com o regime de inspecção 'Ofsted', possam ser vistos como medidas centralizadoras, a maioria das reformas tem sido concebida para promover a escolha parental e transferir responsabilidades das AELs para cada uma das escolas e encarregados de educação" (2002, p. 17)

${ }^{27}$ Em estudo da Rede Eurydice, com o apoio financeiro da Comissão Europeia, intitulado Autonomia das Escolas na Europa, registra-se que "no Reino Unido (Inglaterra), o órgão directivo da escola assume a responsabilidade total pela gestão do pessoal. No entanto, muitas das funções a ela inerentes, como a nomeação de professores e de pessoal não-docente, podem ser delegadas no director ou numa comissão directiva que funciona com ou sem ele. O órgão directivo nomeia o director e, normalmente, conduz o processo de nomeação dos seus adjuntos e assistentes. Tanto no País de Gales como na Irlanda do Norte, a situação é bastante semelhante em muitos aspectos" (2007, p. 32).

28 Ver nota de rodapé 12 sobre a origem das charter schools. 
pedagógicos 'alternativos'. Por último, os autores anunciam um novo formato de privatização da educação pública que denominam de Educational Management Organizations (EMO) o qual, ancorando-se na ideia de que a gestão empresarial é mais eficiente, se caracteriza pela criação de charters por empresas lucrativas, em alguns casos se constituindo em "redes" de escolas charters (2014, p. 272).

Em relação à original experiência de privatização da gestão escolar no Brasil, Leiria, Souto e Saratt (1993), defensores da terceirização na administração pública, tomam a gestão do ensino no Município de Maringá como exemplo de sucesso. Argumentam eles:

não existem divergências quanto à ineficiência do sistema escolar público, seus métodos e índices elevados de evasão. Justo por ir de encontro a esta realidade, a escola cooperativa de Maringá (PR) tem se destacado. Mais ainda por ser um modelo pioneiro de associação do poder público com a iniciativa privada. (pp. 6364).

O trio de advogados não tem dúvidas em proclamar que a terceirização encaminhada pelo Município de Maringá na área de educação é um procedimento administrativo que encarna o espírito de parceria entre o público e o privado: “(...) não há qualquer exagero em afirmar que a escola cooperativa é a prática viva do poder partilhado, essência da terceirização" (Leira et al., 1993, p. 66).

O fato é que as chamadas "escolas-cooperativas" não eram cooperativas na acepção comumente aceita da expressão no que se refere a trabalho compartilhado, cooperatividade e cooperação. A nomeada "escola-cooperativa" de Maringá era organizada como empresa privada, constituída juridicamente como empresa privada e tinha objetivo de lucro como empresa privada. Estas supostas "cooperativas" de ensino de Maringá não foram organizadas por estudantes ou pais de estudantes, tendo em vista a melhoria do ensino ou o compartilhamento de custos com a educação de alunos que, presumivelmente, estariam frequentando escolas particulares.

Os contratos sociais das empresas administradoras das "escolas cooperativadas" maringaenses, de acordo com a natureza consignada em suas constituições, firmam-se como prestadoras de serviços. Isto pode ser comprovado pelo constante no Contrato Social da empresa COEDUCAR S/C LTDA, registrado sob n²401, no livro A-3, no Cartório do Registro Civil das Pessoas Jurídicas de Maringá, que, em sua cláusula segunda, traz o tipo de atividade exercida: a empresa "tem por objetivo social o ramo de PRESTAÇÃO DE SERVIÇOS E ADMINISTRAÇÃO DE COLÉGIOS, ESCOLAS, FUNDAÇÕES E ESTABELECIMENTOS DE CUNHO EDUCATIVO, PÚBLICO OU PARTICULARES" (letras em caixa alta no original) (Paraná, 1991, p. 368).

Além disto, ao examinar o mérito da causa da Ação Civil, impetrada pelo Ministério Público, através da Promotoria de Defesa do Consumidor, o Juiz da 4a. Vara Cível, Dr. Antônio Martelozzo, analisa também a natureza da chamada "escola-cooperativa." O magistrado sentencia que "as nossas Escolas-cooperativas nada têm de cooperativas" (Paraná, 1991, p. 316), fazendo a seguinte referência etimológica:

Segundo Plácido e Silva, em seu "Vocabulário jurídico," o termo cooperativa, derivado do latim cooperativus, de cooperari (cooperar, colaborar, trabalhar com outros), segundo o próprio sentido etimológico, é aplicado na terminologia jurídica para designar a organização ou sociedade, constituída por várias pessoas, visando a melhorar as condições econômicas de seus associados (Paraná, 1991, p. 314). 
Mais adiante, no mesmo texto, o Juiz observa que a educação pública, nesses termos, pode estar sendo objeto de lucro. Citando a Promotoria Pública, registra o magistrado que pode ocorrer de o Município de Maringá "continuar a pagar a conta para que terceiros administrem o ensino público municipal, sob o nome de escolas-cooperativas, obtendo assim lucro, com o apoio de atribuição municipal” (Paraná, 1991, p. 316). Persistindo nesta linha de argumentação jurídica, não se pode deixar de recorrer ao que reza a Constituição da República Federativa do Brasil:

Art. 213 - Os recursos públicos serão destinados às escolas públicas, podendo ser dirigidas a escolas comunitárias, confessionais ou filantrópicas, definidas em lei, que: I - comprovem finalidade não lucrativa e apliquem seus excedentes financeiros em educação; II - assegurem a destinação de seu patrimônio a outra escola comunitária, filantrópica ou confessional, ou ao Poder Público, no caso de encerramento.

Vale, ademais, também destacar o que diz o parecer 187/92, do Conselho Estadual de Educação (CEE), constante no processo n'. 008/92. O relator, a respeito da "escola cooperativa de Maringá", tem o seguinte entendimento:

o que se deduz, em linhas gerais, é que, de fato, bens e recursos públicos são colocados à disposição de uma empresa privada (apesar de constituída por professores), que dispõe de mão-de-obra assalariada (se ao menos 50\% dos professores são donos, os demais, necessariamente, serão assalariados, o que significa que, do excedente de seu trabalho o grupo de professores-sócios poderá se apropriar como 'lucro.' O poder Público municipal cede à empresa privada vencedora da licitação: o prédio público, mobiliado e equipado, os gêneros alimentícios para a merenda, o acervo bibliográfico, os materiais escolares e um pagamento por aluno matriculado (...). (CEE, 1992, pp. 6-7)

É importante ressaltar que o padrão de remuneração deste tipo de empreendimento é o aluno matriculado, isto é, a empresa escolar ganha per capita. Quanto maior o número de alunos na lista de chamada, maior a receita da empresa. Desta forma, caso se consolidasse este modelo de gestão escolar e não fosse tão efêmera a sua existência (1991/1992), poderia ter se construído situações prejudiciais ao processo educativo. Na lógica do capitalismo sem riscos (para o capital) no Brasil, conforme denuncia Florestan Fernandes (1972), a microgestão privada de escolas, conforme a havida em Maringá, pode ensejar efeitos perversos (e riscos) para a educação, tais como:

a) O não registro oficial da evasão escolar. Tal artifício evitaria o rebaixamento da receita da escola-empresa, originada do pagamento per capita (por aluno matriculado) pelo ente público ao grupo privado gestor da escola terceirizada; b) A escola privatizada poderia cobrar taxas de serviços suplementares ou diferenças entre o valor repassado pela Prefeitura e supostos custos "reais" do aluno.

c) O estabelecimento de status diferenciados no atendimento da clientela estudantil, alocada em classes (salas) "A," "B," "C," inclusive com valores diferenciados; d) A demissão de professores filosoficamente críticos ${ }^{29}$;

${ }^{29}$ Pode-se verificar um esboço desses procedimentos coercitivos na reportagem intitulada "Professoras denunciam coação da Prefeitura," do Jornal O Diário do Norte do Paraná: "Vinte professores da Escola Municipal Renato Bernardi denunciaram ontem que estão sendo 'coagidas' pela Secretaria de Educação a 
e) A concentração de capital, com a oligopolização ou mesmo a monopolização dos negócios de gestão do ensino por grupos privados, de modo direto ou por intermédio de $\operatorname{prepostos}^{30}$

f) O desrespeito aos princípios da gestão democrática ${ }^{31}$.

Além disso, pode-se dizer que, com um nível razoável de certeza que, com a criação e implantação da "Escola Cooperativa" em Maringá, quem levou muita vantagem foi o dirigente político do Município, dado o "pioneirismo" na adoção do "Novo Gerencialismo Público" e na implantação de uma modalidade privatista de escolas púbicas. Como percebeu Frigotto, o Prefeito do Município de Maringá foi "alçado a uma espécie de embaixador do experimento no país e até em congressos internacionais" (1994, p. 60). O Instituto Brasileiro de Administração Municipal (IBAM), em texto de divulgação, com o título, Microgestão Privada da Educação e da Saúde no Município de Maringá, elabora a seguinte síntese a respeito da gestão municipal, no período 1989-1992, a gestão do Prefeito Ricardo Barros (1989-1992) à frente da Prefeitura Municipal de Maringá orientou-se por princípios liberais, sendo, inclusive, designada em documentos oficiais como Administração liberal. Entretanto, as idéias do Prefeito são, em geral, mais arrojadas do que as habitualmente defendidas pelos adeptos do neoliberalismo. Como estes, o Prefeito de Maringá defende a redução drástica da intervenção estatal no setor produtivo e, indo além, advoga também a liberação do

assinar o aviso-prévio e obrigadas a trabalhar durante o período de férias. 'Para algumas de nós faltam até quatro meses para concluir o contrato com a Prefeitura, mas, mesmo assim estamos sendo pressionadas a assinar o aviso', contou Elvira Faccin, uma das professoras dispensadas. Elas reclamam também das atividades que deverão cumprir durante o aviso. 'Teremos que trabalhar em creches ou em funções administrativas ao passo que estas não são nossas profissões', disse Isaura Cardoso’ [...]. Para a professora Adriana Beatriz Sobrinho, o fato pode bem ser caracterizado como uma forma de 'coação'. 'Eles não deram opção: ou a gente assina ou fica como abandono de emprego"' (1991, p. 3).

${ }^{30}$ A concentração já ocorria em 1991 e 1992, conforme o promotor público: "Na escola AMAT-ENSINO PRÉ-ESCOLAR LTDA., a professora ANGELA MARIA APOLINÁRIO TARGA é detentora de 95,5\% (noventa e cinco e meio por cento) das cotas [...] O Professor Júlio Cezar Suaki, tido como idealizador do sistema, controla, juntamente com sua esposa (duas escolas), as escolas COEDUCAR S/C LTDA. e PROFESSORES ASSOCIADOS SOCIEDADE EDUCATIVA S/C LTDA" (Brasil, 1991, p. 6-7). Estas duas evidências também ajudam a derrubar a idéia de que se trata de uma verdadeira "cooperativa". A Revista Veja tentou imprimir esta idéia: “... nas escolas públicas de Maringá, todo mundo é sócio - do diretor ao faxineiro - e nenhum pode ter mais que o dobro das cotas do outro" (Veja, 1992, p. 74).

${ }^{31}$ Houve um projeto do Prefeito Ricardo Barros que tencionava extinguir a eleição para diretor das escolas municipais: "Os vereadores adiaram a votação do projeto do prefeito que quer o fim das eleições nas escolas municipais da cidade (...). Professores, diretores e integrantes do Fórum Maringaense em Defesa do Patrimônio Público participaram ontem à tarde da sessão extraordinária na Câmara de Maringá, com o objetivo de impedir a votação do projeto de autoria do Prefeito Ricardo Barros sobre o fim das eleições para diretores das escolas municipais" (O Diaro, 1991, p. 3). Também registra outro periódico local, "O prefeito Ricardo Barros, enviou projeto à câmara municipal, que será discutido em regime de urgência em sessões extraordinárias convocadas para hoje, amanha e quinta-feira, extinguindo a eleição direta nas escolas municipais. Atualmente os pais de alunos elegem as diretoras, pelo voto direto (...)" (Jornal do Povo, 1991, p. 5). 
Estado de todas as atividades de execução e de gerência imediatas. (IBAM, 1992, p. $9-10)^{32}$.

É interessante assinalar que a direção política municipal da época pautou-se pela antiadministração pública. O fito daquela gestão municipal era estender o estilo de privatização da educação para outros setores do serviço público. De acordo com documento de publicação oficial da Prefeitura Municipal de Maringá (1991a):

o conceito de microgestão do serviço público executada pela iniciativa privada pode e vai ser estendido a outros segmentos da administração de Maringá. Já atingiu o setor de creches municipais, em breve vai alcançar os centros esportivos e poderá chegar à área de saúde. A idéia básica é sempre a mesma: quem administra com interesse direto no resultado, administra melhor (p. 3).

Chama a atenção entre as conclusões de um relatório solicitado pela Prefeitura do Município de Maringá, já na gestão sucessora de Said Ferreira (1993-1996) , a evidência de que em lugar do encolhimento da burocracia, o processo de privatização municipal fez aumentar a estrutura burocrática, principalmente nos setores de fiscalização, controle e acompanhamento. Afirma o documento em seu oitavo ponto, com a privatização pretendia-se diminuir a burocracia e o quadro administrativo. $\mathrm{Na}$ prática verificou-se o contrário. Pela necessidade de maior acompanhamento e fiscalização das empresas, a burocracia (documentação) e de pessoal fiscalizador para o controle da presença dos alunos determinou a expansão do quadro funcional da Secretaria de Educação do Município (Jornal do Povo, 1993, p. 4).

De acordo com este relatório, houve aumento do quadro de pessoal em atividades-meio e, desta forma, pode-se dizer que fica anulada uma das razões constantemente apresentadas em defesa das privatizações: a diminuição da burocracia (de pessoal empregado). Ao contrário da fundamentação e dos objetivos propostos, com a terceirização da gestão escolar, por intermédio das chamadas "escolas cooperativas", o corpo burocrático responsável pelo controle e pela fiscalização aumentou.

\section{Considerações Finais}

Em comparação com as experiências norte-americanas de charter school, a Prefeitura do Município de Maringá não abriu a possibilidade de livre escolha por intermédio de uso de vouchers (cheques ou bônus) ${ }^{33}$ fornecidos pelo ente público para pagamento das escolas, que seria uma

\footnotetext{
${ }^{32} \mathrm{Com}$ a criação do gerente municipal, o espírito da eficiência imanente da gerência privada foi demonstrado sem nenhuma mascaração. A execução administrativa fica por conta do manager municipal e a política geral continua reservada à figura pública do Prefeito. Conforme o mesmo IBAM: "Partidário do princípio segundo o qual as funções políticas e técnico-administrativas a serem resolvidas por Prefeito e Secretariado são distintas, requerendo a seleção de atores que bem desempenhem os dois tipos de funções, o Prefeito resolveu solucionar este problema com a criação da figura do Gerente Municipal" (IBAM, 1992, p. 12) ${ }^{33}$ Igor César Franco, organizador de uma das versões de Capitalismo e Liberdade de Milton Friedman, conhecido autor liberal ortodoxo, resume o projeto neoliberal para a educação: "O dinheiro que hoje é mal gasto nos estabelecimentos públicos de ensino deveriam ser convertidos em "vouchers" ou cupons para cada aluno, de tal forma que, com esses recursos, seria possível pagar a mensalidade de uma escola privada. Caberia aos pais escolherem o melhor colégio para seus filhos. A competição que naturalmente se estabeleceria entre as escolas garantiria uma melhoria constante do ensino" (apud Friedman, 2008, p. 8)
} 
forma de as famílias escolherem o estabelecimento escolar para livremente matricular seus filhos. Em Maringá, procedeu-se uma privatização em que a administração municipal, não adotando o bônus, cheque ou vale-educação, terceirizou a gestão das escolas municipais, ao estilo de uma PPP (Parceria Público-Privada). Para isso, o Município de Maringá fez licitação pública e estabeleceu contrato com a empresa vencedora, remunerando-a pelos serviços prestados de administração escolar com a devida liquidação de faturas em dia determinado do mês. A empresa privada encarregada pela "microgestão privada" encaminhava a lista de alunos matriculados à Prefeitura Municipal para receber o montante devido calculado per capita ${ }^{34}$. Portanto, segundo o rito licitatório e de acordo com o contrato entre comprador e vendedor (entre o público e o privado ), a chamada "escola-cooperativa de Maringá" era uma escola por contrato, que conceitualmente é similar a que veio a ser denominada nos EUA de charter school. Conforme Tell, a contratação de serviços permite a privatização e a comercialização da educação. Isso é feito ao se permitir que fornecedores privados desloquem o processo de escolarização de seus tradicionais arranjos públicos e o acomode no setor privado, no âmbito do chamado livre mercado, sujeito à concorrência. A contratação de serviços, nesse sentido, é uma forma diferente de governança, especificamente, a governança pelo 'livre mercado'. É por isso que as escolas charter são escolas desregulamentadas (2015, p. 332) ${ }^{35}$.

No Brasil, posteriormente a existência das "escolas cooperativas de Maringá”, houve outras tentativas de implantação de charter school em Pernambuco e em Goiás. Em Pernambuco, o Programa Estadual de Parceria Público-Privada da Secretaria de Educação do Estado, promoveu o desenvolvimento de Centros de Ensino em Tempo Integral (Procentro), um modelo de charter school implantado em parceria com o Instituto de Co-Responsabilidade pela Educação (ICE), entre os anos de 2005 a 2007. A experiência de Charter School de Pernambuco, popularmente conhecida como Procentro, foi implantada como uma PPP, tendo sido dirigida por organização social sem fins lucrativos e promovida por think tanks como a Fundação Itaú Social e pelo movimento de empresários "Todos pela Educação" (TPE). As charter schools Procentro, implantadas em Pernambuco, de acordo com publicação em conjunta do Instituto Braudel e da Fundação Itaú Social, tinham as seguintes características:

a) Alunos, professores e gestores em regime de dedicação exclusiva e tempo integral (das 7 às 17 horas); b) Critérios específicos e mais rigorosos de seleção, formação e remoção de gestores e professores, sempre com o foco no aprendizado do aluno; c) Possibilidade de contratação de gestores entre educadores aposentados e profissionais de fora da rede pública escolar; d) Sistema de avaliação contínua de gestores, professores e alunos a partir dos resultados de aprendizagem, incluindo o progresso individual dos alunos; e) Diferencial de $125 \%$ no salário do professor da rede, além de um sistema de pagamento de bônus anual para os professores e gestores em função dos resultados de aprendizagem alcançados; f) Criação de um Conselho Gestor responsável pelo gerenciamento de cada Centro, composto de até 15 participantes, com representantes do ICE, da Secretaria de

\footnotetext{
${ }^{34}$ Esta era a obrigação 10.6 expressa no Edital da Prefeitura Municipal de Maringá: "Efetuar, até o dia 05 (cinco) de cada mês, o pagamento por aluno matriculado" (PREFEITURA MUNICIPAL DE MARINGÁ, Edital n. 008/92 DML/DA, 1992, p.7).

35 "Contracting enables the privatization and commercialization of education. It does so by allowing private vendors to take schooling out of its traditional long-standing public arrangements and to place it in the private sector, in the realm of the so-called free market, subject to competition. Contracting, in this sense, is a different form of governance, specifically, 'free market' governance. This is why charter schools are deregulated schools" (Tell, 2015, p. 332).
} 
Educação e de organizações locais da sociedade civil; g) Orientações curriculares claras, com guias de aprendizagem bimestrais por série e por disciplina, diretamente relacionadas ao sistema de avaliação de resultados (Dias \& Guedes, 2010, pp. 26-27).

Em Goiás, houve chamadas para contratos de terceirização de 23 escolas públicas estaduais, a partir de 2016, por intermédio de Organizações Sociais para a execução de "serviços escolares não pedagógicos por meio de PPP (parceria público-privada)" (Gazeta do Povo, 2015). Segundo a matéria jornalística,

via PPP, uma empresa tomaria conta da construção, reformas, manutenção, limpeza e vigilância da escola. Nos dois casos, os diretores das escolas seguirão sendo servidores concursados da educação goiana. A OS vai poder contratar professores e funcionários. Temos 30\% de professores temporários, que em algumas regiões vira 60\%. É um contrato muito precário, disse Raquel Teixeira [Secretaria de Estado da Educação de Goiás]. Na parceria público-privada, você deixa com os professores e com o grupo gestor a responsabilidade pela aprendizagem do aluno, afirmou (Gazeta do Povo, 2015).

Porém, a iniciativa goiana de terceirização das escolas públicas não obteve sucesso, em virtude de movimentos sociais contrários e de ações no âmbito jurídico propostas pelo Ministério Público do Estado de Goiás, não permitindo seu sucesso e impedindo o funcionamento de charter schools no Estado de Goiás (Gazeta do Povo, 2015).

A respeito da qualidade do ensino propriamente dito ${ }^{36}$ desenvolvido pelas "Escolas Cooperativas de Maringá," enfim, deve-se reconhecer que não havia um processo de avaliação, seja performativo, por instrumentos de medida de desempenho, seja formativo, em que os objetivos da avaliação são essencialmente educativos - para a melhoria das práticas pedagógicas (Dias Sobrinho, 2003). Aliás, como percebeu Dativa Gonçalves, em concisa asserção, em relação ao trabalho pedagógico das escolas com "microgestão privada" de Maringá, "quanto à questão pedagógica, ela na realidade, não contava muito nesta proposta. O fundamental era que a Prefeitura passasse toda a gestão da escola para os novos pequenos empresários. Portanto, tratava-se mesmo de privatização da escola pública" (1994, p. 63).

Entretanto, em pesquisa nos arquivos da Prefeitura Municipal, foram encontrados alguns relatórios de visitas às escolas municipais com "microgestão privada" que foram elaborados por coordenadores pedagógicos, lotados na Diretoria de Educação, da Secretaria de Desenvolvimento, em que determinados aspectos da qualidade pedagógica são revelados. Por exemplo, o relatório de visita na Escola João Batista Sanches, de $5^{\mathrm{a}}$. a $8^{\mathrm{a}}$. Séries, no dia 21 de maio de 1992, elaborado pelas coordenadoras pedagógicas das áreas de Geografia, Educação Artística, Educação Física, Inglês e História, informa que “dentre os problemas, são comuns:

\footnotetext{
${ }^{36}$ Não se considerou a comparação feita pela Diretoria de Educação da Prefeitura Municipal de Maringá entre Escola tradicional e "escola-cooperativa" devido ao fato de ter sido feita com instrumentos iguais para escolas diferentes. Explicando: Em 1992, todas as escolas urbanas foram transformadas em escolas cooperativas, somente as escolas rurais continuaram na gestão pública. Sabe-se que há muito mais dificuldades e custos na manutenção das escolas rurais: maior evasão, há menos alunos por sala de aula e há mais gastos com transporte (de alunos e de professores). A Diretoria de Educação fez a seguinte comparação, tomando por base o mês de fevereiro de 1992: -Número médio de alunos por sala na escola tradicional (rural), na $1^{a}$ série:24,08 alunos; -Número médio de alunos por sala na "escola cooperativa" (urbana), na 1ásérie:29,02 alunos. Fonte: Diretoria de Educação da Prefeitura Municipal de Maringá (Paraná, 1991, p. 193).
} 
indisciplina, desinteresse, excesso de faltas e infrequência (8 numa mesma turma), lideranças negativas, notas baixas e alunos que estão sem as notas em algumas disciplinas" (Directoria de Educação, 1992, p. 2). Já na Escola Agmar Santos, em visita no dia 16 de junho de 1992, a mesma equipe de Coordenação Pedagógica constatou a "falta de livros, embora haja memorando assinado de recebimento dos mesmos, na área de ciências, para duas séries, que não retirados" (Directoria de Educação , 1992, p. 9). No dia 22 de junho de 1992, o mesmo grupo de professores visitou a Escola Machado de Assis. Os componentes da comissão fizeram o seguinte registro em relatório:

1) Necessidade de um aparelho de som, essencial para as aulas de Inglês; 2) Número insuficiente de dicionários de Português e Inglês; 3) Falta de livros didáticos, principalmente na área de Inglês (...); 4) Neste bimestre o trabalho foi muito prejudicado pela falta de livros. A Escola não tem condições imediatas de fazer a reposição dos extraviados (Diretoria de Educação , 1992, p. 11).

Ainda no mesmo relatório de visitas, apesar de ser longa a citação, vale a pena a leitura de passagem do registro da equipe de coordenadores pedagógicos a respeito de visita realizada na Escola João Batista Sanches, no dia 19 de Julho de 1992, revelando não somente as dificuldades no trabalho pedagógico, mas também tensões entre a direção da escola, professores da escola e a equipe visitante:

as coordenadoras tomaram a iniciativa, questionando quantos encaminhamentos pedagógicos desenvolvidos durante o bimestre, atendendo as necessidades diagnosticadas no conselho de classe do $1^{\circ}$. Bimestre. As respostas foram vagas, sem objetividade, o que demonstrou a falta de interação do trabalho entre supervisão e professores. A discussão foi bastante dificultada pela presença e pelas intervenções constantes e importunas da diretora da Escola, tentando passar a impressão que o trabalho da Escola corre de forma perfeita. Por exemplo, quando a Supervisora questionava como deveria ser o trabalho do Meio Ambiente, a diretora dizia que tudo já estava pronto. Constatou-se ainda uma contradição nas informações a respeito das aulas previstas e dadas de Português, no decorrer de uma das trocas de professores, ficando evidente que aulas foram registradas, porém não dadas (Diretoria de Educação , 1992, p. 16).

Enfim, o que se pode depreender é que este modelo de escola com "ensino público e gratuito com microgestão privada", a chamada "Escola Cooperativa" de Maringá, similar ao que veio a ser chamado de charter school nos EUA, como uma típica expressão dos tempos de reformas liberalizantes, inclusive pelo estabelecimento de PPPs (Parcerias Público-Privadas), posteriormente consubstanciadas no Novo Gerencialismo Público (NGP), foi uma experiência de privatização de escolas públicas municipais com a transferência, não só de recursos públicos para empresas privadas de serviços educacionais, mas especialmente da responsabilidade da administração escolar, justificada por uma suposta superioridade da gestão privada sobre a gestão pública. É este tipo de administração (por microgestão privada) que se pode classificar como eficiente e eficaz? Afinal, eficiência e eficácia para quem? 


\section{Referências}

Adrião, T. (2014). Escolas charters nos EUA: Contradições de uma tendência proposta para o brasil e suas implicações para a oferta da educação pública. Educação e Filosofia. Uberlândia, 28, (no. esp.), 263-282.

Alves, M. T. G. (2000). Conteúdos ideológicos da nova direita no município de São Paulo: Análise de surveys. Opin. Publica [online] 6,187-225. http://dx.doi.org/10.1590/S010462762000000200002.

Aucoin, P. (1990). Administrative Reform in Public Management: Paradigms, Principles, Paradoxes and Pendulums. Governance: An International Journal of Policy and Administration, 3, 115-137.

Azevedo, M. L. N. (1995) Neoliberalismo e educação: Novo conflito entre o público e o privado. Dissertação (Mestrado em Educação). UFSCar, São Carlos.

Azevedo, M. L. N. (2016). O Novo Regime Fiscal: A retórica da intransigência, o constrangimento da oferta de bens públicos e o comprometimento do PNE 2014-2024. Tópicos Educacionais, Recife (1).

Azevedo, M. L. N., \& Catani, Afrânio M. (2004) Universidade e Neoliberalismo: O Banco Mundial e a Reforma Universitária na Argentina (1989-1999). Londrina: Práxis, 2004.

Baddini, M. (1991). Quase mil pessoas na manifestação contra a privatização da educação. Jornal do Povo, Maringá, 4.

Ball, S. J. (2014) Educação Global S.A. - Novas redes politicas e o imaginário neoliberal. Ponta Grossa: Editora da UEPG.

Bourdieu, P. (1998) Contre-feux. Paris: Éditions Liber-Raisons d'Agir.

Bourdieu, P. (1996) Razões práticas: Sobre a teoria da ação. Tradução M. Corrêa. Campinas: Papirus. Bourdieu, P. (2014). Sobre o Estado. São Paulo: Companhia das Letras. Tradução R. F. d'Aguiar.

Brasil. (1995). Plano Diretor da Reforma do Aparelho do Estado. Ministro da Administração Federal e Reforma do Estado. Brasília.

Brasil. (1988). Constituição da República Federativa do Brasil, CF - 1988.

Bresser-Pereira, L. C. (2001) Do Estado Patrimonial ao Gerencial. In P. S. Pinheiro, J. Wilheim \& I. Sachs (Orgs.), Brasil: Um Século de Transformações (pp. 222-259). S. Paulo: Cia. Das Letras.

Conselho Estadual de Educação. (1992). Escolas Cooperativas de Maringá. Processo n. 008/92. Assembléia Legislativa do Estado do Paraná e Prefeitura do Município de Maringá. Relator: Teófilo Bacha Filho.

Correa, V. L. A. (1993). Avaliação de programas educacionais: A experiência das escolas cooperativas em Maringá (PR). Dissertação (Mestrado em Administração Pública). Escola Brasileira de Administração Pública - Fundação Getúlio Vargas-RJ.

CREDO. (2017) Charter Management Organizations. Center for Research on Education Outcomes, Stanford University. Disponível em $<$ http://credo.stanford.edu $>$.

Dale, R. (2010). A sociologia da educação e o Estado após a globalização. Educação \& Sociedade, 31(113), 1099-1120.

Dias, M. C. N., \& Guedes, P. M. (2010) O modelo de escola charter: A experiência de Pernambuco. São Paulo: Instituto Fernand Braudel de Economia Mundial e Fundação Itaú Social.

Dias Sobrinho, J. (2003) Avaliação: Políticas educacionais e reformas da educação superior. São Paulo: Cortez.

Diretoria de Educação. (1992) Relatório de Visitas. Coordenação Pedagógica da Diretoria de Educação da Secretaria de Desenvolvimento Humano. Prefeitura Municipal de Maringá. Mimeografado. 
Dixon, K. (1998) Les évangélistes du marché. Paris: Raisons d'Agir.

Eurydice. (2007). Autonomia das Escolas na Europa: Políticas e Medidas. Lisboa: Eurydice - Unidade Portuguesa.

Faoro, R. (2000). Os Donos do Poder. Formação do patronato político brasileiro. (2 vols.). São Paulo: Globo e Publifolha.

Fernandes, F. (2006). A revolução burguesa no Brasil. São Paulo: Globo.

Fernandes, F. (1972) Democracia e desenvolvimento: A transformação da periferia e o capitalismo monopolista da era atual. São Paulo: Hucitec.

Freire, P. (1991, 18 out,). Afronta à liberdade. O Diário do Norte do Paraná, Maringá. Entrevista coletiva.

Freire, P. (1991). Paulo Freire não vê futuro promissor para a educação. Jornal do Povo, Maringá, 19 out. de 1991. Entrevista coletiva.

Freire, P. (1996). Pedagogia da autonomia: Saberes necessários à prática educativa. (37. ed.). São Paulo: Paz e Terra.

Fórum Maringaense em Defesa do Patrimônio Público. (1991). Escolas-cooperativas: Uma proposta de privatização da rede municipal de ensino público e creches de Maringá. mimeografado.

Friedman, M. (2008). Capitalismo e liberdade. Extraído de <http://www2.fct.unesp.br/docentes/geo/bernardo/BIBLIOGRAFIA\%20DISCIPLINA S\%20POS-

GRADUACAO/MILTON\%20FRIEDMAN/Capitalismo\%20e\%20Liberdade $\% 20$ -

\%20Milton\%20Friedman.pdf>, acesso em 20 Jan 2018.

Frigotto, G. (1994). Educação e formação humana: Ajuste neoconservador e alternativa democrática. In: P. Gentili \& T. T. Da Silva. Neoliberalismo, qualidade total e educação. Petropólis-RJ: Vozes.

Gadotti, M., \& Romão, J. E. (1993). A educação e o município. Sua nova organização. Brasília: MEC.

Gazeta do Povo. (2015). Goiás prepara parceria inédita com setor privado para escolas públicas.. Extraído de <http://www.gazetadopovo.com.br/vida-e-cidadania/goias-prepara-parceriainedita-com-setor-privado-para-escolas-publicas-ab9xy3k2zdkez2o3vd74qwjoc $>$. Acesso em 10 Fev 2018.

Gonçalves, M. D. S. (1994) Autonomia da escola e neoliberalismo: Estado e escola pública (Tese de doutorado). PUC-SP.

Holanda, S. B. (1995). Raízes do Brasil (26a ed.). São Paulo: Companhia das Letras.

Hood, C. (1995). The "New Public Management" in the 1980s: Variations on a theme. Accounting, Organizations and Society, 20, 93-109.

Hood, C. (1991). A Public Management for all Seasons? Public Administration, 69, 3-19.

Houaiss. Dicionário. Disponível em < https://houaiss.uol.com.br/pub/apps/www/v33/html/index.php\#2 >. Acesso em 01 Fev 2018

IBAM-Instituto Brasileiro de Administração Municipal. (1992). A microgestão privada da educação e da saúde no Município de Maringá. Rio de Janeiro: IBAM/ENSUR.

Lafer, C., \& Peña, F. (1973). Argentina e Brasil no Sistema das Relações Internacionais. São Paulo: Duas Cidades.

Lima, L. C. (2016). Evaluación Hiperburocrática. Profesorado, Revista de Currículum y Formación del Profesorado, 20(3), 87-118.

Lima, L. C. (2012). Aprender para ganhar, conbecer para competir. Sobre a subordinação da educaşão na "sociedade da aprendizagem." São Paulo: Cortez Editora,

Leiria, J. S., Souto, C. F., \& Saratt, N. D. (1993). Terceirização passo a passo: O caminho para a administração pública e privada. Porto Alegre: Sagra-DC Luzzatto, 
Maschio, J. (1992). 'Terceirização' no PR diminui evasão escolar. Folha de S. Paulo, São Paulo, Caderno, $3,3$.

Ministério Público do Estado de Goiás. (2016). Estado e Seduce são acionados por irregularidades no edital para contratação de OS na área da educação. 20 Out 2016. Extraído de $<$ http://www.mpgo.mp.br/portal/noticia/estado-e-seduce-sao-acionados-porirregularidades-no-edital-para-contratacao-de-os-na-area-da-educacao\#.Wn9qSKinHIU>. Acesso em 20 Fev 2018.

Nosella, P., \& Azevedo, M. L. N. (2012) A educação em Gramsci. Revista Teoria e Prática da Educação, 15, 25-33.

O Diário do Norte do Paraná. Maringá, (1991).

Oliveira, D. A. (2015) Nova gestão pública e governos democrático-populares: Contradições entre a busca da eficiência e a ampliação do direito à educação. Educação \& Sociedade, 36, Campinas, 625-646.

Paraná. (1991). Tribunal de Justiça. Processo n631/91. Autor: Ministério Público do Estado do Paraná. Réu: Prefeitura do Município de Maringá. Relator: Negi Calixto. Sentença do Reexame Necessário emitida em 10 de maio de 1995. Processo remetido à Instância superior pela $4^{\mathrm{a}}$ Vara Cível da Comarca de Maringá, após decisão pelo Juiz de direito: Antônio Martelozzo, em 15 de dezembro de 1992. Processo iniciado em 1991.

Polanyi, K. (1980). A Grande transformação. As origens da nossa época. Rio de Janeiro: Campus.

Prefeitura do Município de Maringá (Paraná). (1991a). Escola cooperativa: Ensino público e gratuito com microgestão privada. Maringá: MRM.

Prefeitura do Município de Maringá (Paraná). (1991b). Caderno técnico. Maringá: MRM.

Prefeitura do Município de Maringá (Paraná). (1991c). Maringá: o babitat bumano. Maringá: MRM.

Ravitch, D. (2017, November 19). Must Read! A Major Report on Charter Schools by the Network for Public Education. [Blog]. Extraído de <http://nepc.colorado.edu/blog/must-read $>$, Acesso em 11 Jan 2018.

Robertson, S., \& Verger, A. (2012). A origem das parcerias público-privada na governança global da educação. Educação \& Sociedade, Campinas, 33, 1133-1156.

Romão, J. E., \& Gadotti, M. (1993). A educação e o município: Sua nova organização. Brasília: MEC. (Série Inovações 3).

Sell, C. E. (2016). As duas teorias do patrimonialismo em Max Weber: Do modelo doméstico ao modelo institucional. Anais do X Congresso da ABCP - Associação Brasileira de Ciência Política. Belo Horizonte.

Serva, L. (1992, 2 ago.).Governo tenta privatização do ensino público. Folha de S. Paulo, São Paulo, Caderno 3, 4.

Tell, S. (2015). Can a Charter School Not Be a Charter School? Journal for Critical Education Policy Studies, 13, 315-347.

Whitty, G., \& Power, S. (2002) A Escola, o Estado e o Mercado: A Investigação do Campo Actualizada. Currículo sem Fronteiras, 2, 15-40. (online) <www.curriculosemfronteiras.org> 


\title{
Sobre o Autor
}

\author{
Mário Luiz Neves de Azevedo \\ Universidade Estadual de Maringá \\ mlnazevedo@uem.br \\ http:/ / orcid.org/0000-0003-0563-5817 \\ CV Lattes-CNPq (Brasil): http://lattes.cnpq.br/0385443872804624 \\ Mário Azevedo é professor titular na Universidade Estadual de Maringá e pesquisador do CNPq.
}

\section{Sobre os Editores}

\author{
Almerindo Janela Afonso \\ Universidade do Minho - Uminho \\ ajafonso@ie.uminho.pt \\ https://orcid.org/0000-0001-9879-5814 \\ Sociólogo, Doutor em Educação, Professor Associado (com tenure) da Unversidade do \\ Minho/Portugal e pesquisador do Centro de Investigação em Educação (CIEd). É coordenador da \\ especialidade de Sociologia da Educação e Política Educativa do doutoramento em Ciências da \\ Educação, foi diretor do Departamento de Ciências Sociais da Educação, membro do Conselho \\ Nacional de Educação e Presidente da Sociedade Portuguesa de Ciências da Educação.

\section{Geovana Mendonça Lunardi Mendes} \\ Universidade do Estado de Santa Catarina \\ geolunardi@gmail.com \\ https://orcid.org/0000-0002-8848-7436 \\ Professora Titular do Programa de Pós-graduação em Educação, do Centro de Ciências Humanas e \\ da Educação da Universidade do Estado de Santa Catarina(UDESC). É vice-presidente da \\ Associação Nacional de Pesquisa e Pós-graduação em Educação(ANPED). É editora associada da \\ Revista Brasileira de Educação, da Revista Brasileira de Educação Especial e da Arquivos Analíticos \\ de Políticas Educativas.
}




\title{
Dossiê Especial
}

\section{Políticas de Administração o Gestão em Países da Lusofonia}

\section{arquivos analíticos de políticas educativas}

\author{
Volume 26 Número $132 \quad 15$ de octubre 2018
}

ISSN 1068-2341

\section{(c)}

SORERIGHIS RESERVED O Copyright e retido pelo/a o autor/a (ou primeiro co-autor) que outorga o direito da primeira publicação à revista Arquivos Analíticos de Políticas Educativas. Más informação da licença de Creative Commons encontram-se em http://creativecommons.org/licenses/by-nc-nd/2.5. Qualquer outro uso deve ser aprovado em conjunto pelo/s autor/es e por AAPE/EPAA. AAPE/EPAA é publicada por Mary Lou Fulton Institute Teachers College da Arizona State University . Os textos publicados em AAPE são indexados por CIRC (Clasificación Integrada de Revistas Científicas, Espanha) DIALNET (Espanha),Directory of Open Access Journals, Education Full Text (H.W. Wilson), EBSCO Education Research Complete, ERIC, QUALIS A1 (Brasil), SCImago Journal Rank; SCOPUS, SOCOLAR (China).

Curta a nossa comunidade EPAA's Facebook https://www.facebook.com/EPAAAAPE e Twitter feed@epaa_aape. 


\section{arquivos analíticos de políticas educativas conselho editorial}

Editor Consultor: Gustavo E. Fischman (Arizona State University)

Editoras Associadas: Kaizo Iwakami Beltrao, (Brazilian School of Public and Private Management - EBAPE/FGV, Brazil), Geovana Mendonça Lunardi Mendes (Universidade do Estado de Santa Catarina), Gilberto José Miranda, (Universidade Federal de Uberlândia, Brazil), Marcia Pletsch, Sandra Regina Sales (Universidade Federal Rural do Rio de Janeiro)

Almerindo Afonso
Universidade do Minho
Portugal
Rosanna Maria Barros Sá
Universidade do Algarve
Portugal
Maria Helena Bonilla
Universidade Federal da Bahia
Brasil
Rosa Maria Bueno Fischer
Universidade Federal do Rio Grande
do Sul, Brasil
Alice Casimiro Lopes
Universidade do Estado do Rio de
Janeiro, Brasil
Suzana Feldens Schwertner
Centro Universitário Univates
Brasil
Flávia Miller Naethe Motta
Janiversidade Federal Rural do Rio de
Prasil

Almerindo Afonso

Alexandre Fernandez Vaz

Universidade Federal de Santa

Catarina, Brasil

\section{Regina Célia Linhares Hostins \\ Universidade do Vale do Itajaí, \\ Brasil}

Alfredo Macedo Gomes
Universidade Federal de Pernambuco
Brasil

Jefferson Mainardes

Universidade Estadual de Ponta

Grossa, Brasil

Jader Janer Moreira Lopes

Universidade Federal Fluminense e

Universidade Federal de Juiz de Fora,

Brasil

Debora Nunes
Universidade Federal do Rio Grande

do Norte, Brasil

\author{
Alda Junqueira Marin \\ Pontifícia Universidade Católica de \\ São Paulo, Brasil
}

Dalila Andrade Oliveira

Universidade Federal de Minas

Gerais, Brasil
José Augusto Pacheco

Universidade do Minho, Portugal

Jane Paiva

Universidade do Estado do Rio de Janeiro, Brasil

Paulo Alberto Santos Vieira

Universidade do Estado de Mato

Grosso, Brasil

Fabiany de Cássia Tavares Silva

Universidade Federal do Mato

Grosso do Sul, Brasil

\section{António Teodoro}

Universidade Lusófona

Portugal

Lílian do Valle

Universidade do Estado do Rio de Janeiro, Brasil

\author{
Alfredo Veiga-Neto \\ Universidade Federal do Rio Grande \\ do Sul, Brasil
}




\section{archivos analíticos de políticas educativas consejo editorial}

Editor Consultor: Gustavo E. Fischman (Arizona State University)

Editores Asociados: Armando Alcántara Santuario (Universidad Nacional Autónoma de México), Jason Beech (Universidad de San Andrés), Ezequiel Gomez Caride (Pontificia Universidad Católica Argentina), Antonio Luzon (Universidad de Granada), Angelica Buendia (Metropolitan Autonomous University), José Luis Ramírez (Universidad de Sonora), Paula Razquin (Universidad de San Andrés)

Claudio Almonacid

Universidad Metropolitana de

Ciencias de la Educación, Chile

\section{Miguel Ángel Arias Ortega}

Universidad Autónoma de la

Ciudad de México

Xavier Besalú Costa

Universitat de Girona, España

Xavier Bonal Sarro Universidad

Autónoma de Barcelona, España

Antonio Bolívar Boitia

Universidad de Granada, España

José Joaquín Brunner Universidad Diego Portales, Chile

Damián Canales Sánchez

Instituto Nacional para la

Evaluación de la Educación, México

Gabriela de la Cruz Flores

Universidad Nacional Autónoma de México

Marco Antonio Delgado Fuentes

Universidad Iberoamericana,

México

Inés Dussel, DIE-CINVESTAV, México

Pedro Flores Crespo Universidad Iberoamericana, México
Ana María García de Fanelli

Centro de Estudios de Estado y

Sociedad (CEDES) CONICET,

Argentina

Juan Carlos González Faraco

Universidad de Huelva, España

María Clemente Linuesa

Universidad de Salamanca, España

Jaume Martínez Bonafé

Universitat de València, España

Alejandro Márquez Jiménez

Instituto de Investigaciones sobre la Universidad y la Educación, UNAM, México

María Guadalupe Olivier Tellez, Universidad Pedagógica Nacional, México

Miguel Pereyra Universidad de

Granada, España

Mónica Pini Universidad Nacional de San Martín, Argentina

Omar Orlando Pulido Chaves Instituto para la Investigación

Educativa y el Desarrollo

Pedagógico (IDEP)

José Ignacio Rivas Flores

Universidad de Málaga, España

\author{
Miriam Rodríguez Vargas \\ Universidad Autónoma de \\ Tamaulipas, México \\ José Gregorio Rodríguez \\ Universidad Nacional de Colombia, \\ Colombia \\ Mario Rueda Beltrán Instituto de \\ Investigaciones sobre la Universidad \\ y la Educación, UNAM, México \\ José Luis San Fabián Maroto \\ Universidad de Oviedo, \\ España
}

Jurjo Torres Santomé, Universidad de la Coruña, España

Yengny Marisol Silva Laya

Universidad Iberoamericana, México

Ernesto Treviño Ronzón

Universidad Veracruzana, México

Ernesto Treviño Villarreal

Universidad Diego Portales

Santiago, Chile

Antoni Verger Planells

Universidad Autónoma de

Barcelona, España

Catalina Wainerman

Universidad de San Andrés, Argentina

Juan Carlos Yáñez Velazco

Universidad de Colima, México 
education policy analysis archives
editorial board

Lead Editor: Audrey Amrein-Beardsley (Arizona State University)

Editor Consultor: Gustavo E. Fischman (Arizona State University)

Associate Editors: David Carlson, Lauren Harris, Eugene Judson, Mirka Koro-Ljungberg, Molly Ott,

Scott Marley, Iveta Silova, (Arizona State University)

Cristina Alfaro San Diego State

University

Gary Anderson New York

University

Michael W. Apple University of Wisconsin, Madison

Jeff Bale OISE, University of

Toronto, Canada

Aaron Bevanot SUNY Albany

David C. Berliner Arizona

State University

Henry Braun Boston College

Casey Cobb University of

Connecticut

Arnold Danzig San Jose State

University

Linda Darling-Hammond

Stanford University

Elizabeth H. DeBray University of Georgia

Chad d'Entremont Rennie Center for Education Research \& Policy

John Diamond University of

Wisconsin, Madison

Matthew Di Carlo Albert Shanker Institute

Sherman Dorn Arizona State University

Michael J. Dumas University of California, Berkeley

Kathy Escamilla University of Colorado, Boulder

Melissa Lynn Freeman Adams State College

Rachael Gabriel

University of Connecticut

Amy Garrett Dikkers University of North Carolina, Wilmington
Gene V Glass Arizona

State University

Ronald Glass University of

California, Santa Cruz

Jacob P. K. Gross University of Louisville

Eric M. Haas WestEd

Julian Vasquez Heilig California

State University, Sacramento

Kimberly Kappler Hewitt University of North Carolina Greensboro

Aimee Howley Ohio University

Steve Klees University of Maryland

Jaekyung Lee

SUNY Buffalo

Jessica Nina Lester

Indiana University

Amanda E. Lewis University of Illinois, Chicago

Chad R. Lochmiller Indiana

University

Christopher Lubienski Indiana

University

Sarah Lubienski Indiana University

William J. Mathis University of

Colorado, Boulder

Michele S. Moses University of

Colorado, Boulder

Julianne Moss Deakin

University, Australia

Sharon Nichols University of Texas, San Antonio

Eric Parsons University of

Missouri-Columbia

Amanda U. Potterton

University of Kentucky
Susan L. Robertson Bristol

University, UK

Gloria M. Rodriguez

University of California, Davis

R. Anthony Rolle University of Houston

A. G. Rud Washington State University

Patricia Sánchez University of

University of Texas, San Antonio

Janelle Scott University of California, Berkeley

Jack Schneider University of

Massachusetts, Lowell

Noah Sobe Loyola University

Nelly P. Stromquist University of Maryland

Benjamin Superfine University of Illinois, Chicago

Adai Tefera Virginia

Commonwealth University

Tina Trujillo University of

California, Berkeley

Federico R. Waitoller University of Illinois, Chicago

Larisa Warhol

University of Connecticut

John Weathers University of Colorado, Colorado Springs

Kevin Welner University of Colorado, Boulder

Terrence G. Wiley Center for Applied Linguistics

John Willinsky

Stanford University

Jennifer R. Wolgemuth University of South Florida

Kyo Yamashiro Claremont Graduate University 
